\title{
ANYONE FOR A GAME OF MONOPOLY'M?* A CRITICAL EVALUATION OF THE EVER- INCREASING COMMERCIALIZATION OF MAJOR SPORTING EVENTS PART 3: EXAMINING THE LEGITIMACY OF THE CREATION AND MAINTENANCE OF COMMERCIALLY-DRIVEN MONOPOLIES IN SPORTS EVENTS
}

\author{
Andre $\mathrm{M}$ Louw** \\ BA LLB LLM PhD \\ Faculty of Law \\ University of KwaZulu-Natal, Durban
}

\section{SUMMARY}

This is the third and final part in a series of articles which examines the commercial monopoly in a major sports event such as the 2010 FIFA World Cup South Africa, and its protection against ambush marketing by means of (specifically) domestic legislation. This part will continue the evaluation of the role of relevant constitutional guarantees in terms of the South African Bill of Rights, will consider the justification for the protection of commercial rights to such events, will briefly examine recent developments elsewhere in respect of the development of a 'sports event organiser's right', and includes a concluding section with some critical evaluation of the legitimacy of the current state of the law in this regard in South Africa (and elsewhere).

"The business opportunities that stem from the world's biggest sporting event are plentiful. The infrastructure projects generate lucrative construction and other related tendering contracts, which are often financed by host nations and their governments. The FIFA World Cup is thus a catalyst for competition - not only among football stars, but also among the many private and public contenders for the multiple tenders that flow from these highly financed events. There is ample opportunity for corrupt individuals to influence outcomes through bribes, fraud and extortion, thereby increasing the risk of conflicts of interest and, ultimately, corruption."

* With apologies to US trademark holders Parker Bros. and John Waddington Ltd (licensed manufacturers and distributors of the Monopoly ${ }^{T M}$ board game outside the USA). 


\section{$1 \quad$ INTRODUCTION}

The first part of this article ${ }^{2}$ contained a largely descriptive overview of the practices of ambush-marketing of sporting events, and of the legislative and other measures that are used to protect against such conduct. Part 2 of the article $^{3}$ proceeded to examine the legitimacy of commercial monopolies in sporting mega-events critically, by focusing on some intellectual property law and competition law issues regarding such monopolies and the relevant antiambush marketing legislation that is used to maintain and protect the commercial interests of sports governing bodies and their commercial partners such as sponsors. The second part of the article also commenced an evaluation of the legitimacy of such monopolies and legislation in light of the South African Bill of Rights (specifically in respect of the guarantee of freedom of expression). This third and final part of the article will continue this last evaluation in respect of other relevant constitutional guarantees, and will also include discussion of the arguments raised by sports governing bodies in justification of such monopolies and consider some relevant recent developments elsewhere, with a view to considering the proper way forward in respect of future treatment of these issues in our law.

\section{THE ROLE OF THE BILL OF RIGHTS (CONTINUE):}

\section{Freedom of trade, occupation and profession}

As is clear from discussion of the applicable anti-ambush marketing legislation in South Africa (and elsewhere) in the previous two parts of this paper, restrictions on commercial activity related to protected events potentially limit the freedom of trade of private actors such as entrepreneurs. For example, section 15A of the Merchandise Marks Act ${ }^{4}$ prohibits the use of

** Parts of this article are based on or include material previously published in the author's monograph on "South Africa", in the series International Encyclopaedia of Sports Law Kluwer Law International (September 2009) ISBN 978-90-411-1754-0 (also published as Louw Sports Law in South Africa Kluwer Law International 2010 (ISBN 978-90-411-3314-4) reproduced here with the permission of the publishers, Kluwer Law International BV, The Netherlands. I wish to thank my colleague, Tanya Woker sincerely for her kind comments on an earlier draft of this paper, for taking the time to discuss related issues and for sharing a sentiment of dubious suspension of disbelief in respect of some of the issues and developments relating to the hosting of the 2010 FIFA World Cup as referred to in this paper. $I$ also wish to thank Jo-Ann du Plessis for her invaluable and insightful editorial assistance with an advanced draft of this paper.

1 Schulz-Herzenberg Player and Referee: Conflicting Interests and the 2010 FIFA World Cup $^{T M}$ April 2010 Monograph 169, Institute for Security Studies 3.

2 Published in Obiter 2010 31(1) 57-91.

3 Published in Obiter 2010 31(2) 264-309.

4 This provision was discussed extensively in the first two parts of this article. S 15A of Act 17 of 1941 (as amended by Act 61 of 2002) provides as follows:

"S 15A Abuse of trade mark in relation to event:

(1) (a) The Minister may, after investigation and proper consultation and subject to such conditions as may be appropriate in the circumstances, by notice in the Gazette designate an event as a protected event and in that notice stipulate the date -

(i) with effect from which the protection commences; and 
a trader's own marks in relation to an event. As indicated elsewhere in this paper, such proscribed use may be nothing more than the normal use, in the course of trade, of a proprietor's own trademark, in line with the normal function and purpose of a trademark, but in relation to a protected sporting event. Section 22 of the South African Constitution provides as follows:

"Every citizen has the right to choose their trade, occupation or profession freely. The practice of a trade, occupation or profession may be regulated by law."

The right contained in section 22 mirrors the concept of freedom to trade which is found in the South African common law, although this right is of a more limited ambit than its earlier counterpart in the interim Constitution of 1993. ${ }^{6}$ This concept of freedom of trade has usually been expressed as a public-policy consideration which must be taken into account when deliberating on claims to enforce restraints of trade or to prevent unlawful competition. ${ }^{7}$ One dimension of this concept is that a free and competitive market requires that "personal skills and expertise can be freely bartered"; ${ }^{8}$ a complementary dimension is that persons are entitled to trade without wrongful interference from others. ${ }^{9}$

(ii) on which the protection ends, which date may not be later than one month after the completion or termination of the event.

(b) The Minister may not designate an event as a protected event unless the staging of the event is in the public interest and the Minister is satisfied that the organisers have created sufficient opportunities for small businesses and in particular those of the previously disadvantaged communities.

(2) For the period during which an event is protected, no person may use a trade mark in relation to such event in a manner which is calculated to achieve publicity for that trade mark and thereby to derive special promotional benefit from the event, without the prior authority of the organiser of such event.

(3) For the purposes of subsection (2), the use of a trade mark includes $\square$

(a) any visual representation of the trade mark upon or in relation to goods or in relation to the rendering of services;

(b) any audible reproduction of the trade mark in relation to goods or the rendering of services; or

(c) the use of the trade mark in promotional activities, which in any way, directly or indirectly, is intended to be brought into association with or to allude to an event.

(4) Any person who contravenes subsection (2) shall be guilty of an offence.

(5) For the purposes of this section 'trade mark' includes a mark."

5 The s 22 right is only available to South African citizens (compare the wording of the section, and the Constitutional Court's finding in Certification of the Amended Text of the Constitution of the Republic of South Africa, 1996 ( $2^{\text {nd }}$ Certification decision) 19972 SA 97 (CC) that the right of occupational choice could not be considered a universally accepted human right see Currie and De Waal The Bill of Rights Handbook 5ed (2005) 489.

6 S 26(1) of the Interim Constitution (Act 200 of 1993) provided that "[e]very person shall have the right freely to engage in economic activity and to pursue a livelihood anywhere in the national territory". See Currie and De Waal 484 et seq.

7 See Lagrange in Cheadle, Davis, and Haysom South African Constitutional Law: The Bill of Rights 2ed (2005) Chapter 17-1 fn 2; Magna Alloys \& Research (SA) (Pty) Ltd v Ellis 19844 SA 874 (A); and Sunshine Records (Pty) Ltd v Frohling 1990 (4) SA 782 (A).

8 Atlas Organic Fertilizers v Pikkewyn Ghwano 19812 SA 173 (T) 192F-193E, as quoted in Cheadle et al Chapter 17-1 fn 2.

9 Eg, see Patz v Green \& Co. 1907 TS 427 436-437; and Matthews v Young 1922 AD 492; and Cheadle et al Chapter 17-1 fn 2. 
The proviso in section 22 allows limitation of the freedom to practise a trade by "law". It is in this proviso that constitutional testing of alleged infringements of the right to choose a trade freely will usually find its substance - namely an evaluation of the legitimacy of any restriction of the right in question. The Constitutional Court ${ }^{10}$ has held that an emphasis on freedom of participation in the economy did not implicitly include the right of unqualified persons to practise in professions requiring such qualifications nor did it entitle "persons to ignore legislation aimed at regulating the manner in which particular activities are to be conducted, provided always that such regulations are not arbitrary". ${ }^{11}$ Regarding restriction of the right contained in section 22, Traverso $\mathrm{J}$ declared as follows in the case of Coetzee $v$ Comitis: $^{12}$

"I accept that any profession must be regulated to a certain extent $\square$ these regulations can be internal or imposed by statute. Whatever the case may be, $a$ profession can only be regulated in a manner which is reasonable and in a manner which does not violate the constitutional rights of individuals" (author's own emphasis).

It is clear that any alleged infringement of a person's choice to engage in economic activity in terms of section 22 , which would constitute a limitation of such right, would have to satisfy the proportionality test under section 36 of the Bill of Rights. Any restriction falling short of such a limitation (in terms of the proviso to the right, namely a restriction regulating the manner of participation in such economic activity) must satisfy the "rationality test", which, at least, demands that such restriction must not be arbitrary and that there must be a rational basis for the restriction. Where the restriction on the manner of participation also affects the choice to participate, the limitation test must be satisfied. ${ }^{13}$ Such an analysis raises the importance of the policy issues underlying a regulatory measure, and specifically also the purpose of such measure. ${ }^{14}$ In the context of a section 22 -review it is also important to note that the presence of economic freedom does not mean that there can be no legitimate constraints on the exercise of economic activity - the section 22 right permits persons to be active in the economic domain with all its inherent constraints. ${ }^{15}$ Such constraints and the bases for their existence must satisfy the thresholds for constitutional review. As has been observed:

"There are a host of constraints imposed by the kind of society that the constitution has brought into being, premised as it is on social democratic principles."

When evaluating the justification for restrictive measures or laws which may impact on the freedom of trade, it is submitted that a fruitful analogy may be drawn with the approach to legislative regulation of vocational activity under the German Constitution of 1949 (which in article 12(1)

\footnotetext{
In S v Lawrence; S v Negal; S v Solberg 199710 BCLR 1348 (CC) par 33 of the judgment.

$S v$ Lawrence; $S$ v Negal; $S v$ Solberg supra par 33 of the judgment.

Coetzee $v$ Comitis 20011 SA 1254 (C) par 27 of the judgment.

See Cheadle et al Chapter 17-4.

Cheadle et al Chapter 17-5.

See Devenish The South African Constitution (2005) 139.

Ibid.
} 
contains a provision that is strikingly similar to section $22^{17}$ ). The approach regarding the regulation of vocational activity under the German Constitution has been summarized as follows:

"The general principles governing the regulation of vocational activity may be summarised as follows: The practice of an occupation may be restricted by reasonable regulations predicated on considerations of the common good. The freedom to choose an occupation, however, may be restricted only for the sake of compelling public interest; that is, if after careful consideration the legislature determines that a common interest must be protected, then it may impose restrictions to protect that interest - but only to the extent that the protection cannot be accomplished by a lesser restriction on freedom of choice. In the event that an encroachment of freedom of occupational choice is unavoidable, lawmakers must always employ the regulative means least restrictive to the basic right."

And an added element to consider is the power wielded by the perpetrator (in the horizontal application of the right) of an alleged infringement of the right:

"In principle, the ability to argue the applicability of the right would seem to depend more on the market power wielded by the actor whose conduct is impugned rather than the status of that actor: the more the power wielded enables that actor to control access to an entire market, the more vulnerable that power will be to constitutional attack. This approach might well guide the courts when deciding the appropriateness of applying the right horizontally"19 (author's own emphasis).

It is submitted that, on similar logic, an evaluation of the legitimacy of the limitation of the practice of someone's freedom to trade by a law that is aimed at protecting the rights or interests of specific entities such as sports governing bodies and their commercial partners (as is the case with antiambush marketing legislation such as section 15A of the Merchandise Marks Act), should take into account the market power (and the exercise of such power) by these relevant entities. It is also submitted that the "public interest" referred to should be applied, mutatis mutandis, in the context of antiambush marketing legislation and measures to refer to the "public interest" in free participation in activities - including economic activities - related to major sporting events that are partly publicly funded from taxpayer money, and that also hold (frequently touted if not always evident) socio-economic upliftment implications. Here it should not be forgotten that section 15A(1)(b) expressly emphasizes such socio-economic imperatives in requiring that "the Minister (of Trade and Industry) may not designate an event as a protected event unless the staging of the event is in the public interest and the Minister is satisfied that the organizers have created sufficient opportunities for small businesses and in particular for those of the previously disadvantaged communities". A related element to such public interest in this regard is not only the interest of the public (as supporters of teams and athletes within the relevant sporting code) in having access to the performances of such players at the highest level of competition, but to have

\footnotetext{
17 See Cheadle et al Chapter 17-1 fn 2.

18 Kommers The Constitutional Jurisprudence of the Federal Republic of Germany (1997) 287288, as quoted in Cheadle et al Chapter 17-10 fn 38.

19 lbid.
} 
the freedom to associate with the hype of the events and to express themselves (also through commercial speech) in this regard.

The above approach from German law aims to limit the regulatory infringement of the individual's freedom of choice through scrutiny of both the purpose of the limitation as well as the proportionality of the means chosen to effect such limitation. In this sense it is in line with the section 36 test under the South African Bill of Rights.

It should be obvious that anti-ambush marketing legislation does not, per se, constitute objectionable limitation of persons' freedom of trade; clearly such limitations on commercial freedom may be justifiable even though they have at their heart the purpose to protect, primarily, narrow commercial interests. Legislation aimed at prohibiting association ambushes clearly fortify already existing (and uncontroversial) common law protections against unlawful competition and passing-off and protection against deceptive trade practices.

Once again, however, it is submitted that the same considerations do not apply in respect of "intrusion ambushes". It has been repeatedly emphasized in this paper that this latter type of marketing activity does not necessarily constitute legally or ethically objectionable behaviour; in fact, the only legal objections may stem from anti-ambush marketing legislation, in the manner of a self-fulfilling prophesy. Sports governing bodies lobby (and actively pressure) domestic legislators to sanction otherwise unobjectionable conduct legally, which in turn then provides grounds for arguing that such conduct is, even in the absence of such legislative prohibitions, illegitimate. An example of this, it is submitted, is to be found in the legal strategy pursued by FIFA's local legal representatives in their anti-ambush marketing litigation in the run-up to the 2010 football World Cup. Mention was made elsewhere in this paper of the main pillars of the template for civil action in terms of this strategy, ${ }^{20}$ which includes what has been described as "groundbreaking causes of action and arguments". ${ }^{21}$ What is of specific interest here is the following "groundbreaking" argument:

"In particular, a method had to be devised to enable FIFA to pursue a civil claim against an ambush marketer based on the anti-ambush marketing provisions of s15A of the Merchandise Marks Act, that create a criminal offence. An unlawful competition argument was formulated utilising the principle that, in breaching the criminal provisions and thus entering into direct competition with FIFA's sponsors for the 2010 World Cup, ambush marketers were perpetrating conduct which was objectively unlawful, being a criminal offence, and were causing damage to FIFA by prejudicing its relations with its sponsors"22 (author's own emphasis).

The Explanatory Memorandum to the amendment Bill which inserted section 9(d) of the Trade Practices Act ${ }^{23}$ expressly stated that passing-off

20 See par 3 of part 1 of this article.

${ }^{21}$ By Dr Owen Dean, partner of Spoor \& Fisher (one of the large intellectual property law firms representing FIFA in South Africa), writing in Dean "FIFA Scores Opening Goal" May 2009 Without Prejudice 4-5 - see par 3 of part 1 of this article.

22 Ibid.

23 The legislation that prohibits association ambushes - see discussion in par 226 of part 1 of this article. 
would not be available under the common law in the event of a breach of trade practices law. It is unclear why or to what extent a similar consideration should not apply in respect of the Merchandise Marks Act. ${ }^{24}$ Also, the alleged element of "entering into direct competition with FIFA's sponsors" appears to be a bit of a stretch; section $15 \mathrm{~A}(2)$ does not require a competitive relationship and (as has been pointed out above) also does not require prejudice to a sponsor - this appears to be implicit in the assumed "filching" of publicity value around the event. Be that as it may, it should be noted that in respect of the conduct prohibited by section $15 \mathrm{~A}$ of the Merchandise Marks Act - which clearly includes "intrusion ambushes" which may otherwise constitute perfectly legitimate and non-deceptive conduct - it appears that FIFA has sought to obtain legislative criminalization of conduct which is not prohibited by the common law, and has then succeeded ${ }^{25}$ in fabricating a contravention of the common law based on the contravention of such legislative provisions! The circular nature of the legitimization of this limitation of the freedom of trade of "intrusion ambushers" is, in this observer's view, nothing short of ominous. While it has been observed that section $15 \mathrm{~A}(2)$ does not require the representation of an association with a protected event, the common-law passing-off action does require this. Essentially, it is submitted, this argument creates an irrebuttable presumption of representation of an association, which is illegitimate.

Leaving aside such legal creativity, however, it remains to consider whether the South African anti-ambush marketing legislation (specifically, section 15A of the MMA in so far as it covers "intrusion ambushing") might be open to constitutional challenge based on limitation of the section 22 right. I would submit that the restriction contained in the section clearly contains a limitation of a trader's freedom of trade in respect of the use of its own trademark and the promotion of its goods or services. The question is whether this restriction is reasonable and justifiable in light of the provisions of the limitations clause. As mentioned above, and in terms of the proviso contained in section 22, the restriction on the manner of practicing freedom of trade must not be arbitrary and must have a rational basis. In this regard, I believe it is important to consider what, in fact, is the protected interest at which the prohibition against "intrusion ambushing" in section 15A (and, specifically, section $15 A(2)$ ) is aimed. As has been observed, this provision is not aimed at legislative bolstering of the common-law protection against passing-off, as it does not require deception or confusion of the public regarding an association with a protected event. Section $15 \mathrm{~A}(2)$ specifically prohibits "intrusion ambushing", and one must consider what it actually purports to protect.

The common-law passing-off action is aimed at protecting the goodwill of a plaintiff business, but it also encompasses an element of protection of the public against deceptive and misleading conduct by the defendant. While most jurisdictions protect the public against deceptive trade practices by

${ }^{24}$ See Johnson Ambush Marketing: A Practical Guide to Protecting the Brand of a Sporting Event (2008) $141 \mathrm{fn} 97$.

25 It appears from the rather sparse order in the FIFA $v$ Metcash matter (discussed in par 4 below) that Msimeki $\mathrm{J}$ in the North Gauteng High Court found in favour of this argument by FIFA's legal team. 
means of legislation (compare South Africa's Trade Practices Act ${ }^{26}$ ), the passing-off action reflects a common-law cause of action which also provides a deterrent to deceptive trade practices such as, for example, misleading advertising. As mentioned, section 15A of the MMA does not require any deception or confusion regarding an association with a protected event. Accordingly, it appears to be aimed solely at protecting the goodwill of event organizers and their commercial partners in respect of such an event. I would suggest, however, that the concept of "goodwill" should be more closely examined in this context.

Essentially, the prohibition contained in this provision appears to be more akin to the common-law unlawful competition tort of direct adoption of a rival's performance (what is also referred to as prestasie-aanklamping). ${ }^{27}$ If one considers the wording of section $15 \mathrm{~A}(2)$, it is clear that - at least in terms of the common law - there is nothing objectionable about the use of a mark in relation to an event, which use is calculated to achieve publicity for such mark (this last is, in fact, one of the functions of a trademark). It appears that what is viewed by the legislature as objectionable is when such use of a mark "derives special promotional benefit from the event". Note also that section $15 \mathrm{~A}(3)(\mathrm{c})$ refers to the use of a trademark in terms of section $15 \mathrm{~A}(2)$ as including its use "in promotional activities, which in any way, directly or indirectly, is intended to be brought into association with or to allude to an event". In essence, therefore, what is protected would appear to be the publicity value of the event ("popularity" may be a better word). By analogy with the common-law action for misappropriation of a competitor's performance, it appears that the legislature has prohibited the misappropriation of the publicity of protected events, if one considers the publicity value of an event such as the FIFA World Cup as a product of FIFA - that is, FIFA's organization of the event, with the financial and other assistance of its commercial partners, produces a product in the form of the event; the goodwill in such event includes its significant publicity value. Considered in this light, one can draw an analogy with the locus classicus on misappropriation in American law, International News Service $v$ Associated Press: ${ }^{28}$ FIFA has put time, effort and labour into creating the event and its publicity value; a trader acting in contravention of section $15 \mathrm{~A}(2)$ who acts in a manner that "derives special promotional benefit from the event" is viewed as having filched the product of such labours, that is, the publicity value of the event.

Let's get back to basics for a minute, and consider the dictionary meaning of the word "publicity": One source defines the noun as "the activity of making certain that someone or something attracts a lot of attention from many people, or the attention received as a result of such activity" (author's own emphasis). ${ }^{29}$ Another source gives the following possible meanings:

"(1) Extensive mention in the news media or by word of mouth or other means of communication;

(2) Public notice so gained;

26 See par 226 of part 1 of this article.

27 See Neethling Van Heerden-Neethling's Unlawful Competition 2ed (2008) 231 et seq.

28 (1918) 248 US 215.

29 As defined by Cambridge Dictionaries Online http://dictionary.cambridge.org. 
(3) The measures, process or business of securing public notice;

(4) ...

(5) The state of being publiç or open to general observation or knowledge" (author's own emphasis).

Publicity is, by definition, aimed at the public, is something that is public, cannot exist without being public, and is open to access by the public. The publicity around an event such as the football World Cup is clearly something that is created, not only by the organizers of the event and their commercial partners, but by others (for example, the host government and local organizing committee) and by members of the public themselves, and which, if done properly, persists notwithstanding the active promotional efforts to publicize the event. In this light, it appears nonsensical to argue that it is something that can be "owned" in the traditional sense of the word, by the event organizers. I have in the past written about "image rights" (specifically in the context of professional athletes) and unauthorized merchandising of celebrity, and have referred to the "right of publicity" enjoyed by celebrities in a number of states in the United States of America. ${ }^{31}$ I have argued for recognition of protection in South Africa based on the "right to the earning capacity", as a species of "personal goodwill" that attaches to those who are famous enough to be able to earn income from references to or use of aspects of their personas. I still believe that our law should recognize such an "ownership" of the publicity value of fame in that context (largely because of the prevalence of unauthorized use of aspects of celebrity for gain, and the need for recognition and protection by the law). However, in the context of the present discussion in respect of the publicity value of major sporting events, I believe that one should distinguish the "goodwill" of the event from the publicity value of the event. Of course, the publicity value is clearly an element of the goodwill (and, in monetary terms, would constitute something that would add value to the goodwill of an event, if/when quantifiable). However, I believe that one should distinguish the ordinary meaning of goodwill of a business undertaking as we understand it (also of the commercial undertaking that is the football World Cup, for example) and the fact that such goodwill relates to a spectacle, and a newsworthy one at that. Let's take the example of the goodwill of a "normal" business undertaking, let's say Coca-Cola. In the traditional meaning of the term as accepted in our law, Coca-Cola's goodwill can be defined as "the attractive force that brings in custom". 32 This includes many aspects that add value to the brand of Coke (I am not a marketing or branding expert, and will leave the reader to consider what these are). However, it is my contention that when one deals with an event such as the football World Cup, one should distinguish between the brand of the FIFA World Cup ${ }^{\mathrm{TM}}$ and the fact that the event itself is, well, an event - a spectacle. If one considers the above definitions of "publicity", it is submitted that the publicity value of the brand (part of the goodwill of the business undertaking of FIFA's World Cup)

30 Definition of "publicity" as per Dictionary.com.

31 Louw "Suggestions for the Protection of Star Athletes and Other Famous Persons against Unauthorised Celebrity Merchandising in South Africa" 200719 South African Mercantile Law Journal 272-301.

32 See Commissioners of Inland Revenue v Muller \& Co's Margarine (Ltd) 1901 AC 217 224; and Neethling 99 et seq. 
should be distinguished from the publicity value of the event, that is, of the spectacle.

It is my contention that the latter is in the public domain. The latter is not solely the product of FIFA and its marketing gurus. It is a product of the efforts of FIFA, of the host government, of the people of the host country, the football fans, the media and other sources (including this article, in so far as it discusses the FIFA event and is being read by you, the reader). In fact, and $\mathrm{Mr}$ Blatter will hate me for saying so, those who engage in "intrusion ambush-marketing"; through their references to an event, also add to the publicity surrounding such event (I'll stop short of suggesting that these persons should send event organizers a bill for such promotional activities).

The bulk of the publicity value of the World Cup is due to it being "an event", and a major (and newsworthy) one at that. I do not believe that FIFA or its commercial partners can properly be said to "own" this publicity value; more emphatically, I do not believe that they should have the power to restrain members of the public - the true "owners" (or at least objects) of publicity? - from using such publicity, even for commercial purposes where such use only relates to reference to the event.

There are two other aspects to the legislative restriction contained in section $15 \mathrm{~A}(2)$ that must be considered. The first relates to the criminalization of conduct and the imposition of criminal sanctions in light of the mens rea of an offender. Strict liability where a sanction such as a fine or imprisonment is imposed would not be in accordance with a trader's constitutional rights (and the accepted principle of nulla poena sine culpa). Sanctions can only be imposed on the basis of culpability, taking into account the extent of fault in accordance with generally accepted principles of law, and an automatic criminal sanction would not be proportional and, thus, could be unconstitutional. According to the wording of section $15 \mathrm{~A}(2)$, the element of mens rea which is required for a conviction appears to relate only to the intention to achieve publicity for a mark (that is, where there is use of a mark in relation to an event "which is calculated to achieve publicity for such mark"). As is pointed out elsewhere in this paper, this is in fact one of the normal purposes of trademark use. The intention required on the part of the trader does not appear to include the intention to derive special promotional benefit from an event (such promotional benefit is as a consequence of the use of the mark). I believe that the section seeks to criminalize insufficiently blameworthy conduct.

The second aspect that deserves some attention is the element of the harm caused by a trader who may be convicted of an offence in contravening the section. In referring to the "filching" or misappropriation of publicity to an event (as referred to above), one must ask whether there is any harm in such conduct or, rather, whether the legislature intends for the substantial penalties to accrue even where no such harm can be shown. The ambush marketer is not accused of having stolen a loaf of bread, a car, or a plane. It is submitted that, if one wants to claim that publicity value is one's product, one should also be able to claim that any "misappropriation" of such "product" has in fact made one poorer in some form or other. And this, it is submitted, is completely absent from the restriction contained in section $15 \mathrm{~A}(2)$. Consider the definition of ambush-marketing as contained in the 
eThekwini (Durban) Municipality's By-laws for the 2010 FIFA World Cup, which also make reference to "promotional benefit" regarding the event:

\begin{abstract}
“'Ambush Marketing' means marketing, promotional, advertising or public relations activity in words, sound or any other form, directly or indirectly relating to the Competition, and which claims or implies an association with the Competition and/or capitalises or is intended to capitalise on an association with, or gains or is intended to gain a promotional benefit from it to the prejudice of any sponsor of, the Competition, but which is undertaken by a person which has not been granted the right to promote an association with the Competition by FIFA and whose aforesaid activity has not been authorised by FIFA Competition"33 (author's own emphasis).
\end{abstract}

Here we see an interesting variation on the words "promotional benefit" as found in the Merchandise Marks Act. Section 15A(2) refers to "special promotional benefit", without more, while the above definition of ambushmarketing refers to "promotional benefit ... to the prejudice of any sponsor". Seeing that the same drafter did not draft these two provisions (and realizing that one cannot use a method like comparing two simple mathematical equations), it is assumed that one cannot say that "special" promotional benefit $a$ la the Act refers to promotional benefit which prejudices a sponsor. It is submitted that this highlights the apparent irrationality of the restriction contained in section $15 \mathrm{~A}(2)$. There is no requirement of harm to event organizers or sponsors (as would be the case in terms of the common-law unlawful competition and passing-off actions), and the restriction appears to relate simply to the use of publicity (or "piggy-backing" on an event's popularity). Does our law (apart from this provision) really proscribe this? If so, should it?

Mention was made (in the first part of this paper) to the claim of rights to events in the founding documents of international sports federations like FIFA (compare Article 74 of the FIFA Statutes currently in force at the time of writing). The organization has been described as "both the world governing body of association football and the lawful owner of the world-wide Marketing Rights, Media Rights and all other commercial rights in respect of the [World Cup] Competition". ${ }^{34}$ In determining the protected status of the publicity value of an event like the football World Cup it is submitted that this last statement must be interrogated more closely. The reader should remember that, in terms of South African law, FIFA holds no property right to the event. The marketing rights referred to are simply a restatement of the fact that FIFA has the "right" (that is, is free) to create contractual rights in respect of sponsors and commercial partners. One observer has pointed out that South African law does not recognize a legally protectable "marketing right" as such. ${ }^{35}$ The underlying "property" that forms the basis of such contracts and the rights they create are intellectual property (that is, the licensing of the use of copyright-protected material and registered trademarks) as well as common-law remedies such as unlawful competition and passing-off (that is, FIFA's "marketing rights" are "rights" because the

${ }^{33}$ Par 1.1.6 of the definitions section of the By-laws. For further discussion of the By-laws, see the text below.

34 In the preamble to the 2010 FIFA World Cup South Africa By-laws as published by the eThekwini Municipality for the host city of Durban (see discussion elsewhere in this article).

35 See Burrell "FIFA's Money Grab a Blatant Foul" 12 April 2010 Daily News. 
organization may (and does) prosecute civil claims in cases of unauthorized representations of association with the events). "Media rights" are similarly based in contract - FIFA is not the "author" of broadcasts relating to its events, but the copyright which would in terms of our law vest in the official broadcaster (who creates the copyrighted work) is, by means of an assignment in the broadcasting contract between FIFA and the broadcaster, automatically transferred to FIFA. ${ }^{36}$

Accordingly, it should be clear that such a claim of rights in the founding documents of an organization like FIFA does not create for itself a property right to the event or its publicity value. Apart from the intellectual property (for example, trademarks or copyright-protected broadcasts) and protection of goodwill by means of, for example, passing-off claims, the "marketing rights" that FIFA claims are in terms of the privity of contract not enforceable against third parties. These organizations, however, manage to obtain legislative legitimization of such "rights", as mentioned elsewhere in this paper, by means of anti-ambush marketing legislation in the different jurisdictions. The reader should be under no illusions that this is due to sugar-coated "lobbying": such legislation is obtained through straightforward pressure ("strong-arming") on governments in the bidding process for major events. And, apparently, it doesn't end once the bid has been successful. FIFA has throughout the last 5 years been credited with an apparent "Plan B" in respect of the 2010 World Cup (Brazil and Australia were at different times rumoured to be alternate venues). South Africa's preparation for the event has always proceeded under the proverbial dangling sword of Damocles.

Viewed in the context of prohibitions on "intrusion ambushing", sports governing bodies' justification for anti-ambush marketing efforts - namely the argument that the protection of sponsorship exclusivity is crucial for the attraction of sponsors and the consequent ability to stage such events appears to be an assumption that big sponsorship money is required to create the publicity value of events. In my view this is fallacious: While the amount of hype (and, accordingly, the publicity value) surrounding an event is clearly influenced in part by the size and scope of the event, the real core of the publicity value of major sporting events lies in the actual nature and purpose of the event - that is, the fact that an event like the football world cup represents the pinnacle of international competition in the sport and produces, every four years, a world champion. It appears that the financial justification argument loses sight of the raison d'etre of such events, which has a very significant public domain character. Publicity value of the event is,

${ }^{36}$ Provided that the arrangement with any non-employee production crew/commentators contains appropriate copyright assignments (in terms of $s 21(1)(e)$ of the South African Copyright Act 98 of 1978, for example), the broadcaster will normally be the first owner of the copyright in the broadcast (and accordingly the rights holder in respect of broadcasting of the live event footage and of highlights or clips). The event owner could obtain an assignment of the copyright arising from the broadcaster's production of match footage (which would be contained in the broadcasting rights contract), in return for the granting of a limited license to broadcast the event footage (See Lewis and Taylor Sport: Law and Practice (reprint 2007) 683). Such an assignment of copyright is the norm in broadcast rights license agreements, and copyright normally subsists in the relevant sports federation. For more information on the legal nature of sports broadcasting rights in various jurisdictions, see Blackshaw, Cornelius and Siekmann (eds) TV Rights and Sport: Legal Aspects (2009). 
of course, essential to the sponsors, as their investment requires publicity in order to market the product or service. It is, however, questionable whether (or to what extent) the objective of throwing lots of money at an event in order to increase its marketing value can or should serve to legitimize such a far-reaching prohibition on personal freedoms as contained in section 15A. One must again consider the fact that there is no requirement as to a representation of an association contained in section $15 \mathrm{~A}(2)$, and that other jurisdictions are less willing to criminalize conduct by a trader which doesn't go this far. Compare the finding of the Delhi High Court in India in the matter of ICC Development (International) Ltd v Arvee Enterprises \& Philips, ${ }^{37}$ where Philips had offered ICC Cricket World Cup 2003 tickets in a promotional campaign. The court held that there was no likelihood of confusion that Philips was a sponsor of the event (which they weren't), and dismissed passing-off and unfair trading claims. In respect of the practice of intrusion ambush-marketing, the court held that this practice was distinguishable from passing-off, as there is no element of deceit in intrusion ambush-marketing but merely opportunistic commercial exploitation of an event. The court held that this is not contrary to the public interest, and that as long as an official sponsor's trademarks are not used, ambush-marketing is not illegal and it is in line with commercial advertising as free speech in terms of the Indian Constitution. ${ }^{38}$

In its efforts to challenge ambush-marketing before the South African courts, FIFA has consistently claimed that it is the publicity value and goodwill of the World Cup event which is in fact being infringed. For example, in the Metcash matter ${ }^{39}$ FIFA claimed that its World Cup tournaments have received significant publicity and public interest in South Africa and that, as a result of an enormous repute and goodwill in the 2010 event, there are "strong common law rights in that event", which vest in FIFA. ${ }^{40}$ One must, however, also ask whether the publicity value of such an event is to be considered properly the exclusive property of the event organizer, and whether there is a legal basis for the legislative prohibition on deriving "special promotional benefit" (for example, also through mere allusion to the event ${ }^{41}$ ) from such an event. It is my view that there are some major impediments in the way of a claim to exclusive ownership of or entitlement to the publicity value of an event by the event organizer and/or its commercial partners. These include the following:

- As discussed elsewhere in this paper, South African law does not recognize a property right to the spectacle of a sporting event;

- in respect of the publicity value (and goodwill) of a major event, one must consider to what extent such publicity value is due solely to the efforts of the organizers; in this regard, the considerable role of public funding, infrastructure development etcetera, by host governments must be taken

372003 (26) P.T.C. 245 (Del.)

38 Vassallo, Blemaster and Werner "An International Look at Ambush Marketing" NovemberDecember 200595 The Trademark Reporter 13381347.

39 See discussion in par 7 below.

40 At par 11.1 of FIFA's heads of argument in the Metcash matter.

41 See s $15 \mathrm{~A}(3)$ of the Merchandise Marks Act. 
into account in determining the extent to which major events and their publicity value may be (at least partly) in the public domain;

- one must also consider the nature of the events, and the extent to which, for example, football's pinnacle of international competition resides in the public domain. This is in fact recognized by regulators - compare the listing of major events as events of public interest in terms of sports broadcasting rights regulations, in order to prevent exclusive broadcasting rights to such events being sold to pay-TV operators and to ensure access for the masses; and

- finally, in light of the above analogy to the common law tort of misappropriation of a rival's product, one should consider whether or the extent to which "intrusion ambushing" conduct (that is, a marketing campaign in which reference is made to a protected event without claiming or causing confusion regarding the existence of an association with such event) constitutes filching of publicity or mere reference to information which is (or should properly be) in the public domain - it is submitted that the catch-22 scenario that confronts an organization such as FIFA is that its substantial efforts to market the World Cup as the world's biggest sporting event in fact causes such event to be extremely newsworthy. The sporting event becomes a major international event, and it attracts publicity as a result.

It should be noted that major sporting events hold the potential for increasing economic activity and for expanding economic investment in multiple areas (not only limited to infrastructure development and the construction of world-class stadia). Indeed, this is often touted in justification for the public funding required to host such events - compare the South African experience in respect of FIFA's World Cup. In this regard, it is interesting to note the following sentiments as expressed by the European Sponsorship Association (or ESA): ${ }^{42}$

"[We believe] that protection should not be provided for the financial interests of a small number of major brands and events at the expense of wider economic benefits and indeed sponsors of other entities. Major events traditionally give rise to a large upswing in marketing spend across the board, with advertising campaigns themed around the event and a range of opportunities to exploit sponsorships of other properties that are not officially related to the event itself. Specific anti-ambush legislation should not be allowed to stifle the financial 'dividend' generated in the wider economy generally, especially where the host nation has had to invest specifically in order to stage the event."

Major events, arguably, serve to stimulate such a financial dividend in the wider economy and, as such, stimulate trade. It is submitted that the legitimacy of limitations on the freedom of trade of individuals who attempt to reap the benefits of such dividend through otherwise legal and unobjectionable conduct (compare the "intrusion ambushers") should be examined against this backdrop, and the rationale of protection of the public interest and common good which must underlie a justifiable limitation of the section 22-right should be paramount.

42 From the European Sponsorship Association's Position Statement on Ambush Marketing, 14 October 2005. 
In this regard I would submit that we are required also to consider the impact of protection against ambush-marketing of protected events outside of the specific legislation, in assessing the extent to which anti-ambush marketing measures limit the freedoms of individuals (including their freedom of trade). For example, let's consider the provisions of the host city by-laws that were passed in respect of the 2010 World Cup. In considering the extent to which anti-ambushing measures limit the freedom of trade (as well as personal freedoms) of individuals, it is submitted that one need look no further than these - what I shall call "draconian" - provisions, which have been enacted in what I shall characterize as an atmosphere of insufficiently motivated protectionism and extensive legislative overreach in respect of the World Cup event. As an example I shall include some brief words on the 2010 FIFA World Cup South Africa ${ }^{T M}$ By-laws adopted by host city Durban's eThekwini Municipality. ${ }^{43}$ I shall mention only a few examples of the extremely invasive nature of the prohibitions and restrictions contained in these by-laws, which include the following:

(1) The By-laws provide that "no person may, in any place owned, leased, administered by or under the control of the Municipality" engage in any Advertising or erect and/or position any Advertising Structure without the prior Approval of the Municipality. When one considers the very loose definition of "advertising" in the By-laws, ${ }^{44}$ it appears that if I place my empty soda can on the sidewalk, I am "advertising" to the public that my soda is finished, for which I need the Municipality's prior approval; $;{ }^{45}$

(2) The provisions on Controlled Access Sites ${ }^{46}$ contain a number of rather severe prohibitions that, at the very least, may be difficult to police. For example, "no person shall except with the written approval of the Municipality":

43 Published in March 2009, in terms of the Municipal Systems Act 32 of 2000. Host cities are in terms of the Bid guarantees and following selection as host city required to pass such Bylaws (which, to this author's knowledge, are based on a standard template drafted or commissioned by FIFA). This is explained in the preamble to the Durban By-laws:

"[T]he eThekwini Municipality ... has assumed certain obligations with regard to the Competition and in particular, has agreed to ensure that appropriate by-laws are passed to enable the efficient running of the Competition. In this instance, the eThekwini Municipality is required to ensure that appropriate by-laws in the areas listed below are promulgated and implemented, and become effective for the Term to enable an orderly and efficient staging and hosting of the Competition: Advertising; Controlled Access; Public Open Spaces and City Beautification; Public Roads and Traffic Guidance; as well as Street Trading."

44 "Advertisement" is defined in par 1.1.3 of the By-laws as meaning "a visual representation including but not limited to a sign, illustration, object, mark, symbol or device of any kind which is visible to the public from, including but not limited to, any street or any public place or any other vantage point or which is under or over-hanging from any bridge, building or other structure, including sky writing, used for advertising activity; or any combination of such elements with the object of transferring information" ("advertising" is, in turn, defined in par 1.1.4 to mean "the act or process of notifying, warning, informing, displaying, making known or any other act of transferring information in a visual or oral manner").

45 Par 2.1.1.2 of the By-laws.

46 As defined in par 1.1.21 of the By-laws. Controlled Access Sites include stadia, official event locations, official training sites, team hotels, official hotels for the FIFA delegation, FIFA Fan Parks, and any other area so designated or demarcated by the Municipality, and including private property. 
- smoke, eat, drink or sleep in any Controlled Access Site where these activities are forbidden;

- use abusive or otherwise objectionable language or behave in an abusive, objectionable or disorderly manner in a Controlled Access Site;

- hamper, disturb, obstruct or harass any other Person using and/ or entering any Controlled Access Site;

- spill or drop any substance that may cause danger or harm to any user of a Controlled Access Site;

- lie, sit, stand, congregate or walk, in a manner that otherwise causes an obstruction of any nature whatsoever, within any Controlled Access Site;

- deposit or leave or cause to be left any object which may endanger or cause harm to or be a Nuisance to any user of a Controlled Access Site; or

- throw any object, of any nature whatsoever, within or onto a Controlled Access Site.

(3) In respect of the "Public Open Spaces and City Beautification" provisions, ${ }^{48}$ there are also quite stringent limitations on what one may or may not do. First, consider the provision requiring that "all persons engaged in major construction during the term which is visible to the public view and close to major or concentrated transport centres or entertainment areas which will or may be used for the competition ... shall take all necessary measures at their own cost to cover and/or conceal such construction sites from public view to the satisfaction of the Municipality". ${ }^{49}$ And beware if you are planning to "plant any vegetation" in a Public Open Space ${ }^{50}$ without the Municipality's prior express authorization, or "capture or attempt to capture, chase, shoot at, injure, throw objects at, tease, molest or in any other way disturb any animal, fish, or bird or its nest or egg". ${ }^{51}$ That's not the end of it. "No person shall at a Special Event or in a Public Open Space, in particular, or in any other area within the Municipality, in general, without the Approval of the Municipality" (inter alia) -

- beg or solicit money in a Public Open Space;

- cause a Nuisance including play loud or offensive music;

- camp or reside;

- perform any action prohibited in terms of any sign erected by the Municipality in a Public Open Space; or

- consume any beverage from a glass container. ${ }^{52}$

47 Par 3.5 of the By-laws.

48 Chapter 4.

49 Par 4.1 .1

50 This is defined in par 1.1.62 of the By-laws.

51 Par 4.6.

52 Par 4.2. 
(4) The provisions regarding street trading (note the definitions in this regard which appear to be rather circular and nonsensical ${ }^{53}$ ) are similarly extensive, ${ }^{54}$ so much so that it is beyond the scope of this paper to discuss.

These By-laws are characterized by what this observer views as apparent blatant legislative overreach, even though this may be in part ascribable to rather sloppy drafting in places. ${ }^{55} \mathrm{~A}$ cynical observer may be excused for reading between the lines to find a clear and rather sinister message from FIFA to the great "unwashed masses": "We're coming to your city. If you can't afford to buy a ticket to one of our games (where you'll have to wear what we allow you to wear and eat and drink only what we allow you to) GET OUT NOW!"

Apart from the host city by-laws, other measures have also been put in place to control aspects of trading around the FIFA event. In early 2010 the draft Liquor Control Policy for the 2010 FIFA World Cup was gazetted by the Department of Trade \& Industry, ${ }^{56}$ to be greeted by public outcry especially from the hospitality industry. Initial reactions to what was perceived as a requirement for existing liquor license holders to obtain a costly special license during the event were highly critical (in reaction to the draft policy's wording, which required venues hosting "any public viewing event" where matches are broadcast "to the general public or otherwise" to obtain a special license). The DTI has attempted to set the record straight by explaining that the liquor control policy will only require a special license in respect of venues such as pubs, clubs, bars and restaurants that intend to charge an admission fee or similar surcharge for the screening of 2010 World Cup games (which establishments will require the permission of FIFA for this purpose). According to reports, such license will have to be obtained at a cost of R50 000 each and 2\% of traders' revenues. There have been reports of proposed legal challenges to the policy, inter alia on the basis that it is alleged to be ultra vires of national government to regulate liquor licensing, which is a provincial competency in terms of the Constitution and relevant liquor legislation. At the time of writing the period for public comment on the draft policy has expired and the Minister of Sport and Recreation is expected to issue regulations in this regard prior to the event in terms of the provisions of the 2010 FIFA World Cup South Africa Second Special Measures Act. ${ }^{57}$

And then, finally, one must consider the impact of a combination of antiambushing legislation, other measures aimed at curbing commercial activities related to the World Cup and also the existing "web" of contractual arrangements that FIFA have in place in respect of the event. For example,

53 "Street trader" is defined (in par 1.1.74) as "a person selling goods", and "street trading" (in par 1.1.75) as "the selling of any goods by a street trader".

54 See Chapter 6 of the By-laws.

55 Eg, par 1.1.18 of the definitions defines "Competition" as including the 2010 FIFA World Cup as well as the 2009 Confederations Cup, which was not held in Durban. Another example is the word "Culture", which is exhaustively defined in par 1.1.22, even though the word does not appear anywhere in the By-laws. Also, as for over-inclusive drafting, see the definition of "sign" as per par 1.1.70.

56 GG 32878 Vol 535 of 2010-01-18.

57 Act 12 of 2006. 
let's consider accommodation. FIFA's exclusive official accommodation provider for the 2010 World Cup, the controversia $\left.\right|^{58}$ Match Events Services, had reportedly (at the time of writing) signed up $80 \%$ of the available rooms in South Africa's top hotel chains. It had by October 2009 finalized contracts for 40000 rooms. Match has thus been enabled to dictate prices to tourists, which has been defended as a measure to counter exorbitant pricing by local accommodation providers - a seemingly noble endeavour. Match's "2010 FIFA World Cup SMME (small, medium and micro enterprises) accommodation agreement" stipulates that guest houses are allowed to charge the rate they "customarily" levied in June 2007, plus a 16 per cent mark-up. The guest house sells the room to Match, which then on-sells it to tourists as the only company allowed to market itself as FIFA's "official" accommodation provider. Not surprisingly, this arrangement caused great unhappiness amongst a number of accommodation providers, who are faced with marketing their rooms "unofficially" in a climate of stringent anti-ambush marketing laws as discussed in this paper. ${ }^{59} \mathrm{I}$ am not aware of whether any of FIFA's famous cease-and-desist letters found their way to such accommodation providers. However, it bears mentioning that it has subsequently emerged that Match (self/FIFA-appointed protector of the hard-earned dollars of foreign tourists) is charging a 30\% mark-up on rooms to guests over and above the price at which guest houses sold such rooms to Match. Also, in some cases (for example, in respect of accommodation in the Kruger National Park) it appears that Match is charging as much as $1000 \%$ more than the normal rate for rooms during the World Cup event! $!^{60}$

In considering whether the relevant anti-ambush marketing legislation and other measures such as described above may constitute illegitimate infringement of the freedom of trade as encapsulated in section 22 of the Bill of Rights, one should consider whether such extremely invasive limitations are reasonable and justifiable in our open and democratic society, in terms of the limitations clause of the Bill of Rights. While this is an exercise that is beyond the scope of this paper, I would submit that such legislation and measures would likely not pass the test of constitutionality, and are liable to be struck down.

\section{The right to property}

Section 25(1) of the Bill of Rights guarantees the right to property, and provides that "no one may be deprived of property except in terms of law of general application", and "no law may permit arbitrary deprivation of property". According to section 25(4)(b), "property" is not limited to land, and would include intellectual property (such as, for example, copyright or a trademark). ${ }^{61}$ Our courts have held that a deprivation of property includes

58 See note 59 below.

59 See the discussion by Rose in Schulz-Herzenberg (ed) Player and Referee: Conflicting Interests and the 2010 FIFA World Cup ${ }^{T M}$ April 2010 101-108.

60 Ibid.

61 '"Property' for purposes of $s 25$ should therefore be seen as those resources that are generally taken to constitute a person's wealth, and that are recognized and protected by law. Such resources are legally protected by private law rights - real rights in the case of physical resources, contractual rights in the case of performances, and intellectual property 
any substantial interference with or limitation of the use, enjoyment or exploitation of private property which "goes beyond the normal restrictions on property use or enjoyment found in an open and democratic society". ${ }^{62}$ The role of the term "normal" has been criticised for being unclear, and it has been suggested that emphasis should rather be placed on the word "substantial" rather than "normal":

"Whether normal or abnormal, an interference with property must be of sufficient gravity, have sufficient impact on the rights of the property holder, to merit being considered a deprivation."

Section 25(2) deals with the expropriation of property (which may only occur for public purposes or in the public interest, and against payment of compensation). An expropriation must be made with an expropriatory purpose; laws or conduct that has another purpose but that has the effect of taking of property does not qualify as expropriation. Accordingly, it would appear that a law such as section 15A of the MMA - even if ostensibly aimed at the public interest or for a public purpose (such as purporting to protect the commercial rights of event organizers and their commercial partners in order to facilitate the hosting of an event such as the 2010 FIFA World Cup), would not constitute an expropriation of the use and enjoyment of a trade mark that might be justified in terms of the Bill of Rights.

The "arbitrariness" provision in section 25(1) requires that the deprivation of property by a law of general application must be both procedurally fair and not arbitrary in its substance; "[i]t requires state interference with private property, whether it amounts to expropriation or not, to be authorized by law and to meet a basic standard of justification". ${ }^{64}$ Furthermore, our courts have held that the requirement that a deprivation of property in terms of section 25 must not be arbitrary in substance is a demanding test; as a first step one must determine the reason for a deprivation, and then one must assess the sufficiency, as a matter of justice and logic, of the relationship between the deprivation and its purpose. Arbitrariness is assessed by means of a test that is specific to the property clause, and that falls somewhere between a mere rationality enquiry and the proportionality enquiry used to assess the limitation of rights in terms of section $36 .{ }^{65}$

It is beyond the scope of this paper to attempt a detailed analysis of the question whether the prohibition on "intrusion ambushes" as contained in section $15 \mathrm{~A}(2)$ of the MMA constitutes a deprivation of property (in the meaning of the use and enjoyment by a trademark holder of their mark in the course of trade) and, if so, whether such deprivation is procedurally or substantively arbitrary. I believe that this question at least bears

rights in the case of intellectual property ... Should an individual's possession or exercise of any of these rights be interfered with arbitrarily or taken over without compensation, s 25 will be available to protect that individual." See also Currie and De Waal 539-540.

62 Mkontwana v Nelson Mandela Metropolitan Municipality 20052 BCLR 150 (CC) par 32 (per Yacoob J); and see also First National Bank of SA Ltd t/a Wesbank v Commissioner, South African Revenue Services 20024 SA 768 (CC).

63 Currie and De Waal $541 \mathrm{fn} 35$.

64 Currie and De Waal 534-535.

65 Currie and De Waal 545; and First National Bank of SA Ltd t/a Wesbank v Commissioner, South African Revenue Services supra par 65. 
consideration, in light of the extremely far-reaching nature of this provision as discussed elsewhere in this paper. Section $15 \mathrm{~A}(2)$ is not based in the common-law protections that exist in respect of deceptive and misleading marketing practices which would constitute passing-off. The section requires no association or deception or implication of association between the "ambush-marketer's" mark and event organizers' marks; it requires no infringement of a trademark, copyright or other intellectual property; and it requires no likelihood of confusion amongst the public regarding a connection between the mark and the protected event. In essence, the section places a restriction on a rights holder to use and enjoy their intellectual property "in relation to an event", when such use is calculated to achieve publicity for such mark and thereby derives special promotional benefit from the event.

It is suggested that this section in fact facilitates the deprivation of property in the sense of constituting substantial interference with or limitation of the use, enjoyment or exploitation of intellectual property which "goes beyond the normal restrictions on property use or enjoyment found in an open and democratic society"', as referred to above. While it has been observed that the effect of a finding of a contravention of section $15 \mathrm{~A}(2)$ of the MMA is that a trademark holder is free to continue using its mark and must simply ensure that it is used in other ways without alluding to a protected event, ${ }^{66}$ it is submitted that this is a rather simplistic argument. There is clearly a limitation of the use of such mark which may be substantial. It is submitted that regard must be had to the circumstances, such as those discussed in this paper: If one considers the virtual "carpetbombing" of publicity surrounding an event such as the football World Cup and the (what I have argued to be) illegitimately wide restriction as contained in section $15 \mathrm{~A}(2)$ in respect of otherwise legally and ethically unobjectionable conduct by a trader in tapping into public interest and sentiment through its marketing efforts (as well as the long period of protection afforded by the legislation), the above argument may be tantamount to saying "don't complain, you can still use your mark, just go do it on some island somewhere far away from the hype of this event and the market for your product or service".

Without engaging with this issue in detail, it is suggested that a potential section 25 challenge may lie against the working of section $15 \mathrm{~A}(2)$ of the MMA in respect of its effect on the rights of trademark holders regarding the use and enjoyment of their intellectual property. In this regard it might be relevant to remember that the Constitutional Court has held that the right to hold intellectual property is not universally accepted as a fundamental human right, and that it thus does not require recognition as such in our Bill of Rights. ${ }^{67}$ However, this view has been criticized, and the same court, in a trademark infringement by dilution action, in effect gave equal status to a

66 See the blog posting by Owen Dean on 13 October 2009 on the afro-ip blogspot http://afroip.blogspot.com (accessed 2010-04-09).

67 In re Certification of the Constitution of the Republic of South Africa 199619964 SA 744 (CC) 799 
statutory trademark right and the fundamental right to freedom of expression as protected in the Bill of Rights. ${ }^{68}$

\section{IN DEFENCE OF THE MONOPOLY: EVALUATING THE ARGUMENTS IN FAVOUR OF CONTRACTUAL AND LEGISLATIVE RING-FENCING OF COMMER- CIAL RIGHTS TO MAJOR SPORTING EVENTS}

In $2008^{69}$ FIFA showed a surplus of USD 184 million. $^{70}$ Of its revenue of USD 957 million for the year, USD 903 million represented event-related revenue (that is, $94 \%$ of total revenue, and up from USD 786 million in 2007). Of this amount, the organization earned more than USD 550 million from the sale of television broadcasting rights in respect of the 2010 FIFA World Cup South Africa ${ }^{\mathrm{TM}}{ }^{71}$ and USD 253 million from marketing rights (USD 246 million of this specific to the 2010 event). ${ }^{72}$ It should be noted that it has

68 Laugh It Off Promotions CC v South African Breweries International (Finance) B.V. t/a Sabmark International 20061 SA 144 (CC); and see Dean Handbook of South African Copyright Law (looseleaf - service issue 13, 2006) 1-2A fn 3 (and the authority cited there).

69 FIFA's Financial Report 2008 is the most recent financial report for the organization publicly available on its website at the time of writing.

70 It was reported in March 2010 that FIFA declared a profit of USD 196 million and that it had increased its reserve fund to more than USD 1 billion in its Financial Report 2009. The organization declared equity of USD 1.061 billion. It was reported that FIFA has focused on building its reserves in recent years to sustain it in the event that a World Cup is cancelled and commercial partners have to be repaid. It originally had a target of USD 800 million to be set aside by the end of 2010, but has already exceeded that - see the short report of 19 March 2010 on the Business Report website http://www.busrep.co.za/index.php?fSectionld $=552 \&$ fArticleld $=5397601$ (accessed 2010-03-31).

71 The recognized revenue in 2008 from television broadcasting rights for the 2010 FIFA World Cup ${ }^{\mathrm{TM}}$ amounts to USD 550,085 million. The accumulated amount recognised (excluding hedge accounting effects, value-in-kind transactions and sales commissions) for the period 1 January 2007 to 31 December 2008 amounted to USD 1,105,360 million. Until 31 December 2008 , the accumulated amount of USD 971,829 million had been collected - from Note 1: Revenue from Television Broadcasting Rights at 74 of the FIFA Financial Report 2008.

72 Note F ("Revenue Recognition") of the Notes on the Consolidated Financial Statements contained in the FIFA Financial Report 2008 explains the revenue relating to events as follows:

"Event-related revenue primarily relates to the sale of the following rights:

- Television broadcasting rights;

- Marketing rights;

- Hospitality rights; and

- Licensing rights.

Under these revenue-generating contracts, FIFA receives either fixed royalty payments or royalties in the form of guaranteed minimum payments plus additional sales-based payments (profit share). Revenue directly related to the FIFA World Cup ${ }^{T M}$ event is recognized in the income statement using the percentage-ofcompletion method, if it can be estimated reliably. The stage of completion of the FIFA World Cup ${ }^{\mathrm{TM}}$ event is assessed as incurred evenly over the project preparation period, which is four years. While this generally applies to fixed royalty and guaranteed minimum payments, additional sales-based revenue (profit share) is included in the percentage-of-completion method only when the amount is probable and can be measured reliably. Revenue relating to other FIFA events is deferred during the preparation period and is recognized in the income statement when the event takes place. Ticket sales in connection with the 2010 FIFA World Cup South Africa $^{\mathrm{TM}}$ and the FIFA Confederations Cup South Africa 2009 are not recognized, 
been claimed that the organization has, overall, earned significantly more income from sale of rights sources to the 2010 event than is reflected in the above figures for $2008 .{ }^{73}$

For this period, event-related expenses constituted the organization's largest item of expense, namely USD 441 million, of which USD 345 million represented expenses relating to the 2010 World Cup. ${ }^{74}$ Thus, with eventrelated expenses making up $57 \%$ of total expenses and football development expenses of $17 \%$ of the total, FIFA proudly proclaimed that $74 \%$ of its overall expenditure for 2008 represented a direct reinvestment in football. ${ }^{75}$ It is unclear whether the USD 462 million income in respect of events-related activities (that is, the events-related revenue minus eventsrelated expenses) was "reinvested directly in football"; even if all the development project expenses for that year (USD 133 million) were financed directly from such event-related surplus, it appears that FIFA showed a surplus of USD 329 million from sources related to the organization of events. ${ }^{76}$ Ultimately, the organization's USD 184 million revenue surplus that is, profit - appears to have been largely attributable to income directly associated with the organization of events, which is clearly FIFA's main stock-in-trade. ${ }^{77}$ In this light, the organization's motto - "For the Game, For

since the 2010 FIFA World Cup Organizing Committee South Africa is the beneficiary of the net revenue."

73 Rose (118) observes as follows:

"For the 2010 World Cup, revenue generated through 'sale of rights' between 2007 and 2010 amounted to $\$ 3,2$ billion, according to documents provided to the author. This was made up of $\$ 2$ billion for TV rights (63 per cent of the total), with $\$ 1$ billion for the marketing rights, $\$ 120$ million for the hospitality rights, and $\$ 80$ million for licensing. World Cup sponsors, like beer brand Budweiser and cellular firm MTN, also pay FIFA a fee but this is included in the marketing rights."

74 Event-related expenses as recorded in FIFA's financial report are the gross outflow of economic benefits that arise in the ordinary activity of organizing an event. Since FIFA organizes the FIFA World Cup ${ }^{\mathrm{TM}}$ event over a period of four years, expenses relating to the event are recognized based on the stage of completion of the event, as determined for event-related revenue recognition purposes. The end of 2008 reflected a point roughly halfway in the four-year period between the 2006 and 2010 world cup events.

75 From FIFA's Financial Report 2008, as tabled at the $59^{\text {th }}$ FIFA Congress, Nassau, 2-3 June 2009 (the most recent financial report for the organization available on its website at www.fifa.com).

76 FIFA's published financial report for the year 2008 as discussed here does not clarify or itemize expenses related to either events or to development projects. It should be mentioned here, just as a matter of interest, that allegations have been made regarding an apparent decision by FIFA's executive committee, in or about sometime in 2000, that expense claims of members do not need to be supported by documentary proof. Andrew Jennings recounts one instance of an unnamed member who, allegedly, claimed a total of approximately USD 85000 for travel and accommodation expenses without providing any proof of the actual expenses incurred - see Jennings Foul! The Secret World of FIFA: Bribes, Vote Rigging and Ticket Scandals (2006) 101-102. Without expressing a view on such allegations, it is interesting to speculate to what extent income from events finds its way back into the game of football.

77 Compare Note E ("Income Statement") of the Notes on the Consolidated Financial Statements contained in the FIFA Financial Report 2008, which explains event-related revenue and expenses as follows:

"Event-related revenue and expenses are directly related to the organisation and realisation of the FIFA World Cup ${ }^{\mathrm{TM}}$ and other FIFA events. For accounting purposes, FIFA defines other FIFA events as all other football events, such as the FIFA Women's World Cup ${ }^{\mathrm{TM}}$, FIFA U-20 World Cup, FIFA U-17 World Cup, FIFA U-20 Women's World 
the World" - appears to presume that the world of football needs, primarily, big football events. In fact, one could be excused for assuming that FIFA's main role in world football is not to oversee the governance of the game (on which FIFA spent USD 46 million in 2008 - interestingly, just marginally more than the USD 42 million spent on wages and salaries ${ }^{78}$ ), to write the rules of the game or to develop the game, but to organize big and expensive showcases for profit. On such a reading, FIFA's aggressive attempts to protect and exploit the commercial rights to its events appear to be understandable, even reasonable.

FIFA's current commercialization model in respect of the world-cup event can be summarized as follows:

"In line with FIFA's marketing and TV strategy, FIFA sold the television broadcasting rights in the key markets for the final competitions of the 2010 and 2014 FIFA World Cups ${ }^{\mathrm{TM}}$ directly to broadcasters. For the 2006 FIFA World Cup ${ }^{\mathrm{TM}}$, the rights were sold in packages to intermediaries. In the area of marketing, FIFA has implemented a new strategy from 2007 onwards and now distinguishes between FIFA Partner, FIFA World Cup Sponsor and National Supporter. In this context, the number of FIFA Partners has been reduced from 15 in the 2003-2006 period to six for the 2007-2010 cycle. The revenue from television and marketing rights is received from large multinational companies and public broadcasters.

In 2008, FIFA derived income from marketing rights specific to the 2010 FIFA World Cup South Africa ${ }^{\mathrm{TM}}$ in the amount of USD 246 million, ${ }^{80}$ which was split as follows between the three main sponsorship categories:

- "FIFA Partners", USD 148 million;

- "FIFA World Cup Sponsors", USD 73 million; and

- "National Supporters", USD 8 million.

Cup, FIFA U-17 Women's World Cup, Olympic Football Tournaments, FIFA Futsal World Cup, FIFA Confederations Cup, FIFA Club World Cup, FIFA Beach Soccer World Cup, Blue Stars/FIFA Youth Cup, FIFA Interactive World Cup, etc."

78 FIFA Financial Report 200883.

79 See the FIFA Financial Report 2008 96. FIFA "Partners" are awarded the most comprehensive package of marketing rights; FIFA "Sponsors" are granted the second most comprehensive package of rights, and FIFA "National Supporters" are granted a package of specified marketing rights that are only exercisable within the borders of the host nation. In respect of the Olympic Games, the International Olympic Committee utilises six revenuegenerating programmes:

- IOC-managed broadcast sponsorships;

- the TOP partners sponsorship programme (referred to elsewhere in this paper);

- the IOC official supplier and licensing programme;

- domestic sponsorship programmes run by the local Organising Committees for the Games (or "OCOGS");

- ticketing programmes in the host country; and

- licensing programmes in the host country.

By way of example of the revenues generated through these streams between 2001 and 2004, broadcasting rights generated USD 2,232 million, the TOP programme USD 663 million, and domestic sponsorships USD 796 million - see Davis The Olympic Games Effect: How Sports Marketing Builds Strong Brands (2008) 157.

80 According to the report (76), the accumulated revenue from marketing rights recognized (excluding value-in-kind transactions and sales commissions) in 2008 amounted to USD 437 million. The accumulated revenue from marketing rights collected in the period from 1 January 2007 to 31 December 2008 amounted to USD 474 million. 
If one considers FIFA's profit from events and the rather paltry (in comparison) sum spent on football development as reflected for the 2008 financial year, one may be excused for finding the following statement laughable:

"FIFA was established in the legal form of an association pursuant to articles 60ff. of the Swiss Civil Code. Pursuant to article 2 of its Statutes, FIFA's objective is to improve the game of football constantly and promote it globally, particularly through youth and development programmes. FIFA is a non-profit organization and is obliged to spend its profits, reserves and funds for this purpose."

In light of what has been said regarding the apparent creation of a commercial monopoly in FIFA events and the aggressive steps taken to protect such monopoly, one might also find some food for thought in the statement that FIFA strives "to prevent all methods or practices which might jeopardize the integrity of matches or competitions or give rise to abuse of Association Football". ${ }^{82}$ I am not the first to suggest that FIFA's non-profit credentials are rather suspect. ${ }^{83}$

Of course, rapid (and rabid) commercialization of major sports events is nothing new. The "doyen of American sports law", Jim Nafziger, prophesied as long ago as 1988 the important implications for the further development of international sports law by the International Olympic Committee's recognition of the "inevitability and benefits of commercialization". The author did so following a comparison of dollar figures between the 1932 and 1984 Olympic Games, both of which were hosted in Los Angeles, and observed that ticket-sale revenue in 1932 was USD 1.5 million compared to USD 90 million in $1984 .^{84}$ Apart from the phenomenal role of the advent of television as a vehicle to bring sport to the masses of sports entertainment consumers, which has been mentioned elsewhere ${ }^{85}$ the role of sponsorship has been extremely significant in the modern commercialization of sport:

"Sponsorship of major sporting events is keenly sought to the extent that modern day sport at the public entertainment level would be unimaginable without certain companies attaching themselves to the Olympics, cricket, soccer and horse-racing, to name but a few."

It should not be assumed that commercial activities such as sports sponsorship are such very modern phenomena; one of the earliest examples of corporate involvement in sport can be traced back to the Circus Maximus in ancient Rome where gladiators and chariot drivers dressed in the colours of their supporting merchants. Consider also the roles assumed by the

81 Note K ("Income Taxes") of the Notes on the Consolidated Financial Statements contained in the FIFA Financial Report 200867.

82 Article 2(e) of FIFA's Statutes (August 2009 version currently in force at the time of writing), entitled "Objectives".

83 Compare Andrew Jennings's entertaining read on alleged corruption within FIFA and world football, in Jennings, A Foul! The Secret World of FIFA: Bribes, Vote Rigging and Ticket Scandals (2006).

84 Nafziger International Sports Law (1988) 155-156.

85 In the introduction to Part 1 of this article.

86 Grayson Sport and the Law 3ed (1999) 445. 
names "Wisden" in cricket $^{87}$ and "Derby" in horse-racing. ${ }^{88}$ In fact, sponsorship has been an instrumental part of sport for longer than many will care to admit. So, how should one judge the role and importance or, more tricky, the legitimacy, of commercialization in modern sport? Does one take a "purist" stance and, relying heavily on the purported values of Corinthian ideals and the supposed merits of amateurism, decide that big money in sport is all bad? Or does one recognize the many opportunities that are created by the revenues obtained from sponsors and broadcasters, to develop not only "the game" but also, in countless instances, young and often disadvantaged talent, and to uplift whole communities? For example, while it was observed above that an organization such as FIFA appears to be generating very substantial revenues from the organizing of events and the licensing and commercial arrangements surrounding such events, one should not lose sight of the fact that, for example, FIFA contributes towards the travel and other expenses of qualifying teams for its world cup events ${ }^{89}$ and also to tangible development efforts in member countries (for example, through the development of pitches and facilities in rural and underdeveloped areas). It also makes an annual contribution towards the operating costs of its member federations. ${ }^{90}$ Granted, the expenses related to such efforts appear to be a mere drop in the ocean in terms of the organization's revenues, but some sponsor- and broadcaster-generated income clearly does find its way to the grass roots of the game and actually contribute to interests beyond those of the organizers and sponsors.

The point, however, in evaluating the argument so often raised by organizations such as FIFA for aggressively combating ambush-marketing namely, that if sponsors' exclusivity cannot be protected, sponsors would withdraw and the events would be no more - is that it appears that only a fraction of the current sponsor and broadcaster spending that goes towards the major events is actually required "for the good of the game". If one compares the position regarding the FIFA World Cup with the Olympic Games, it is interesting to note that the International Olympic Committee retains around $8 \%$ of revenues from the Games to cover its operating costs, and the remaining $92 \%$ is allocated to National Olympic Committees, international federations and the local organizing committees for the Games events. ${ }^{91}$ It appears that FIFA is much less generous in sharing revenues from its major events with the real stakeholders in the game of football.

87 Grayson (446) describes how John Wisden, a Worcester sports outfitter, decided in 1863 to underwrite the publication of the Wisden Cricketers' Almanack (and how the name "Wisden" has become more synonymous with cricket than with the sponsor's business).

88 The word "derby", which has of course assumed much wider usage in modern times, originated from Lord Derby's financial patronage of horse-racing in England.

89 From the FIFA Financial Report 2008 105:

"FIFA organises the FIFA World Cup ${ }^{\mathrm{TM}}$ and other FIFA events. In connection with these competitions, FIFA offers financial support to local organising committees and compensates teams for travel and acommodation expenses. For the FIFA World Cup ${ }^{\mathrm{TM}}$, the qualifying teams also receive a subsidy to cover the cost of their preparations."

90 FIFA's Financial Assistance Programme is a financial aid programme, under which USD 1 million is granted to each member association and USD 10 million to each confederation during the four-year cycle to improve their administrative and technical infrastructure - FIFA Financial Report 200881.

91 Davis 157. 
While FIFA has on occasion defended its efforts to draw maximum commercial benefit from the World Cup event on the basis that the revenues generated are needed to finance the organization's activities in the four-year period until the next World Cup, it still appears as if a relatively small part of such revenues actually goes towards e.g. development and governance programmes. Yes, less sponsor money would mean smaller events, but it appears disingenuous to argue that the sport would suffer significantly as a result. Would smaller events really be all that bad? At what cost the everescalating spectacles of opening and closing ceremonies and the other activities that surround the hosting of major sporting competitions? Does the maintenance of the huge (and ever-increasing in size) major events justify the apparent trampling of the rights of those outside the hallowed circle of event organizers and their commercial partners, as discussed elsewhere in this article?

In this regard it is important to consider the origins of the massive commercialization of "mega-events" as we encounter it today, which reached heady momentum in the last decades of the previous century. As mentioned elsewhere, a turning point in such developments was the 1984 Olympic Games hosted in Los Angeles, where then IOC president Juan Antonio Samaranch and head of the local organizing committee, Peter Ueberroth, devised the new phenomenon of sponsorship exclusivity and categories of sponsorship as opposed to the open-access model known theretofore (in terms of which anyone who wanted to sponsor an event could get involved). As mentioned, this notion of exclusivity ${ }^{92}$ has been a major reason for the increased practices of "ambushing" of events by non-sponsors who suddenly found themselves outside the candy store looking in. As has been observed, this evolution of sponsorship exclusivity in terms of what would develop into Samaranch's "TOP" ("The Olympic Partners") model, which was initiated in 1985 and inaugurated at the 1988 Seoul Olympics, was devised at a time when the International Olympic Committee was experiencing serious financial problems and when hosting the expensive Games was not an attractive option for potential host cities (for example, only Los Angeles bid for the 1984 Games, but it managed to report a USD 225 million surplus). ${ }^{93}$ Since the inception of this new sponsorship model - which one observer has referred to as "a corporatization and McDonaldization of the world sporting event"

92 The following has been observed in respect of sponsorship exclusivity in the context of the United States sports sponsorship market:

"For sponsors of sport, categorical exclusivity is crucial for achieving [the objective of blocking competition] because it prevents the competition from entering into a sponsorship arrangement with a team, event, or governing body whose exposure is large and whose demographics fit the target market of the industry ... [T] he pursuit of categorical exclusivity is driving service industry sponsorship within highly competitive business sectors such as banking, insurance and telecommunications. A survey of active sport sponsors found that almost half considered exclusivity to be an important aspect of their sponsorship agreements, with 40 percent indicating willingness to pay a 9 percent premium for the right to block the competition." Irwin, Sutton and McCarthy Sport Promotion and Sales Management 2ed (2008) 169-170.

93 See Johnson "Look Out! It's an Ambush" 208 2(3) International Sports Law Review 24.

94 Gruneau "The McDonaldization of the Olympics" in Tomlinson and Whannel (eds) Five-Ring Circus - Money, Power and Politics at the Olympic Games (1984), as referred to in Tomlinson "The Making of the Global Sports Economy: ISL, Adidas and the Rise of the 
in 2004) have either broken even or made a profit for its organizers. ${ }^{95}$ In the 2005-2008 Olympic quadrennial, the 12 TOP sponsors paid a total of USD 866 million in sponsorship fees, of which revenues approximately $40 \%$ was allocated by the IOC to national Olympic committees and $50 \%$ to local organizing committees. ${ }^{96}$

Also, one should consider that the process and rationale behind these developments appear to have had little to do with the "good of the game". If one critical observer is to be believed, developments around the commercial rights structure of the 1984 Games came in the wake of alleged secret dealings between "über-sports" marketer Horst Dassler (son of sports shoe king Adi - "he of the three stripes") and Samaranch, through which Dassler had manoeuvred to install Samaranch at the helm of the IOC and in return received the contracts to market the commercial rights in respect of more than a decade of Olympic Games through the mechanism of Dassler's rather shady International Sport and Leisure, or ISL (which, later, also managed to obtain the rights to market FIFA World Cup events) ${ }^{97}$ Patrick Nally, one of the instrumental players in the development of the commercial programme for the FIFA World Cup, brokered (along with Horst Dassler) the seminal global Coca Cola football sponsorship which was to be the first of its kind and the model for the development of global sports sponsorship as we know it today. ${ }^{98}$ It is truly interesting to note the views of this "insider" about the effect of Coca Cola's involvement in football and its effect on the stature and status of major sports federations like FIFA:

"[The federations] ... are in some ways, because of Coca Cola, beyond reproach. There's no government checking on them. There's (sic) no auditors checking them ... They have the same aura [as Coca Cola] of credibility and extreme cleanness and Coca Cola helps that and yet they can get away with blue murder ... but if the can of worms ever really got open and people started challenging why [the federations] have the ability to do what they do and why they are there and why do they get all these things ... - then I think Coca Cola are going to get a lot of stick from it and Coca Cola's image is going to suffer immensely.

This article will not investigate the frequent claims of widespread corruption in international sport and sports organizations, but it is submitted that, in evaluating the justifications for commercial monopolies in events and the measures imposed to protect them, due regard should be given to the

Corporate Player in World Sport" in Silk, Andrews and Cole (eds) Sport and Corporate Nationalisms Berg Publishing (2005) 36.

95 Gruneau, as referred to in Tomlinson 24-25. The Winter Games in Albertville in 1992 reportedly made a USD 57 million loss. By way of example, the Sydney 2000 Summer Games cost an estimated USD 3.24 billion to present (including a bid cost of USD 12.6 million) and broke even; The Salt Lake Winter Games of 2002 cost an estimated USD 1.3 billion to present (including a USD 7 million bid cost) and showed an estimated USD 100 million profit - see Davis 68 .

96 See Davis 163-164.

97 See Jennings Chapter 3.

98 Coca-Cola has, of course, long recognized the benefits of involvement in sport for building and maintaining its brand value; it is the longest-running Olympic sponsor and has been directly involved in all the Games since 1928.

99 Nally, as quoted by Tomlinson in Silk, Andrews and Cole (eds) Sport and Corporate Nationalisms Berg Publishing (2005) 46. 
fact that "for the good of the game" mantras must be considered in the light of what is, most probably, not a squeaky-clean industry which has at its heart such lofty agendas as the promotion and development of sport for the benefit of the masses. Commercialization and the profit margin loom large in the minds of those who control and organize the major events. Tomlinson describes how FIFA took a leading role, through Sepp Blatter's predecessor Joao Havelange, to establish new economic partnerships during the last few decades of the $20^{\text {th }}$ century which would become a template for the political economy of world sport: ${ }^{10}$

"FIFA's capacity to generate such deals was premised upon its supra-national status. As an INGO (international non-governmental organisation) - a body with a global remit, but no accountability to any particular national government or governments ... - FIFA could offer the potential of worldwide markets to its commercial partners. And as an OFC (offshore financial centre) - 'a centre that hosts financial activities that are separated from major regulating units (states) by geography and/or legislation, ${ }^{, 101}$ - FIFA could assume a fiscal autonomy that could service a cosmopolitan and luxury lifestyle for its operatives and, crucially, broker distinctive deals for the marketing of the game. That the organisation was based in Switzerland, such a prominent international center for OFC dealing, expedited the pace and the scale of such transformative transactions.

[The FIFA of Havelange and Blatter] were not driven by any selfless goal of global equity within FIFA, more by the entrepreneurial motivation and machiavellian global networking of FIFA's bosses and their business allies ... In such contexts and circumstances, global markets for sports business and for major sponsors have expanded with little or no reference to the wider constituencies of sport, or to the ruling forum of individual sports organisations. Benefits may have accrued to under-resourced areas of the football world, but such expansion has been driven by the commercial interests of an incestuous network of sports leaders, administrators and commercial entrepreneurs."

It is this observer's view that the commercial profit-making motive is only very slightly tempered by the supposed "greater good" benefits of major events. A number of studies have been done regarding the actual benefits to host countries and their peoples of events such as, for example, the Olympic Games and FIFA World Cup. ${ }^{102}$ Some have found that, historically, the actual net economic impact of hosting mega-events has been very small compared to initial estimates and predictions by those promoting the events $^{103}$ (it has been reported, for example, that members of London's legislative assembly have expressed the opinion that the originally estimated

100 Tomlinson 59-60.

${ }^{101}$ Quoting Hampton "Where Currents Meet: The Offshore Interface between Corruption, Offshore Finance Centres and Economic Development" in Harriss-White and White (eds) Liberalisation and the New Corruption: IDS Bulletin (1996) 27(2) 210-228.

${ }^{102} \mathrm{See}$, eg, Matheson and Baade "Mega-sporting Events in Developing Nations: Playing the Way to Prosperity?" 2004 72(5) South African Journal of Economics 1069-1075; see also the report entitled "An African Football World Cup at Last! But what will be the effects? Maximizing positive impact of the 2010 FIFA World CupTM" 5-7 March 2008 Results of the International Symposium on the Impact of Mega Sports Events on Developmental Goals, Stellenbosch, South Africa; and Mabugu and Mohamed "The Economic Impacts of Government Financing of the 2010 FIFA World Cup" 2008 08/08 Working Paper of the Department of Economics and Bureau for Economic Research at the University of Stellenbosch.

${ }^{103}$ Compare Baade and Matheson "The Quest for the Cup: Assessing the Economic Impact of the World Cup" June 2004 38(4) Journal of Regional Studies 343-354. 
cost of USD 6 billion to host the London Olympics in 2012 is likely to escalate to approximately USD 29 billion ${ }^{104}$ ), while it has also been observed that the potential economic impact study which was prepared for the South African government prior to the 2010 World Cup bid was "overlyoptimistic". ${ }^{105}$ It was reported in April 2010 that the SA Revenue Service had confirmed that it was not expected that the World Cup event would add any revenue to the fiscus in this financial year. ${ }^{106}$ Without wanting to appear unduly cynical, I would suggest that, at best, the jury is definitely still out on the extent to which, if at all, these major events provide real benefits apart from short-term promotional gains and commercial profits to the small inner circle of heavyweight corporate interests. It is unknown whether sufficient hard evidence exists of wider socio-economic and other benefits which would serve to justify commercial monopolies in events, especially in light of the competition law and constitutional implications of the effects of the severe restrictions on the freedoms of individuals and businesses that now characterize such events in all the jurisdictions where they are held. It is submitted that the following claim by FIFA in response to a freedom of expression challenge in its recent anti-ambush marketing litigation against Metcash in the Gauteng North High Court ${ }^{107}$ is indicative of the organization's apparent stance on the role of the public interest in respect of its commercial activities:

"[I]it is not only the interests of [FIFA] that have to be taken into account, but also ... the interests of the greater public ... A golden thread that runs through all trade mark intellectual property statutes, the common law relating to trade marks (notably passing off) and also, to a certain extent, section 15A of the MMA ... is also the right of the public not to be deceived ... If a respondent utilizes his freedom of expression rights or his own intellectual property in a manner that would deceive or confuse the general public and, in addition jeopardize an event such as the Soccer World Cup and prejudice its sponsors and licensees it would be a justifiable limitation on its rights to freedom of expression in terms of section 36 of the Constitution" ${ }^{\text {"108 }}$ (author's own emphasis).

While I would agree with the first part of this claim regarding the public interest in prohibiting deception of consumers, it is submitted that FIFA's claim to the serving of a "greater public good" in the protection of the

104 Davis 72.

105 See Bohlmann "Predicting the Economic Impact of the 2010 FIFA World Cup on South Africa" May 200611 Working Paper Series, University of Pretoria Department of Economics 13. Cottle "Workers Battle and CEOs Cream it While World Cup Costs Soar" 13 July 2009 Cape Times observed the following:

"In 2004, the financial impact report for the South African World Cup bid committee (prepared by Grant Thornton) estimated the cost of infrastructure and stadiums to the taxpayer would be about R2.3 billion. By October 2006 this amount had increased to R8.35 billion. The current estimated costs to the taxpayer of the stadiums and related infrastructure is $\mathrm{R} 17.4$ billion."

${ }^{106}$ From a report on SABC News, 9 April 2010. The author is not in possession of figures in respect of government's investment in the 2010 World Cup event to date (it was reported by government in February 2008 that such investment in terms of contributions to the 24 World Cup projects amounted (at that time) to ZAR 28 billion).

107 Federation Internationale de Football Association (FIFA) v Metcash Trading Africa (Pty) Ltd Gauteng [2009] ZAGPPHC 123 - see the discussion in par 4 below.

${ }^{108}$ Par 29.4-29.6 of the Applicant's Heads of Argument. 
commercial interests of its event and the monopoly that it enjoys along with its commercial partners is perched on much less solid ground.

At the very least it is hoped that organizations like FIFA will in the near future be called upon to put forward a real case in this regard, before a forum such as the European Court of Justice or even the international Court of Arbitration for Sport. It appears that domestic courts, also in South Africa, have been reluctant to rock the boat on those occasions where the huge commercial sports monopolies have been challenged by those small players who have attempted to obtain financial benefit from a partly taxpayer- and publicly-funded event such as the football World Cup, as the following section will illustrate.

\section{FIFA BEFORE THE SOUTH AFRICAN COURTS: ANTI-AMBUSH MARKETING LITIGATION IN THE RUN-UP TO THE 2010 FIFA WORLD CUP SOUTH AFRICA $^{\text {TM }}$}

FIFA has in the last five years aggressively enforced its commercial rights and those of its commercial partners in respect of the 2010 world cup event by means of litigation (or otherwise ${ }^{109}$ ) in South Africa. In April 2009 it was reported that FIFA had obtained a court order against a tavern in Pretoria, which is situated close to the Loftus Versfeld stadium (a 2010 match venue), to remove World Cup-related signage. The tavern had placed the words "World Cup 2010" beneath the main sign on its roof, and had erected banners featuring the flags of prominent football-playing nations with the numeral "2010" and the words "Twenty Ten South Africa" on them. An application was launched in the Gauteng North High Court claiming interdicts against the tavern owners on the grounds of infringing FIFA's registered trademarks ("WORLD CUP 2010", "SOUTH AFRICA 2010" and "TWENTY TEN SOUTH AFRICA"), for passing-off under the common law, and unlawful competition through the violation of section $15 \mathrm{~A}$ of the Merchandise Marks Act and section 9(d) of the Trade Practices Act. The matter was settled and a consent order granted. ${ }^{110}$ One observer has remarked that it appears strange that the words detailed in the consent order are not protected by the General Notice by which the Minister of Trade and Industry prohibited the use of certain words in terms of section 15A of the Merchandise Marks Act. ${ }^{11}$

A potentially important test case regarding the ambit and interpretation of the 2010 FIFA World Cup anti-ambush marketing protection measures was

${ }^{109}$ It has been claimed (although this sounds rather unrealistic to this author) that FIFA has investigated approximately 50000 cases of alleged infringement of its commercial rights to the 2010 World Cup event in South Africa to date, compared with the 3700 cases that were investigated by FIFA in respect of the 2006 FIFA World Cup Germany - see the report by Seale "FIFA are Bullies" website of Independent Online Newspapers http://www.iol.co.za (accessed 2010-04-12)

${ }^{110}$ See http://www.themarketingsite.com/live/content.php?Item_ID=8980 (accessed 2009-0423).

${ }^{111}$ From a blog posting by Roshana Kelbrick on 8 May 2009 on the afro-ip blogspot http://afroip.blogspot.com (accessed 2010-04-09). 
brought in the Gauteng North (formerly Pretoria) High Court. ${ }^{112}$ This matter involved an application by FIFA against South African retail group Metcash Trading Africa for an order prohibiting the use of a mark, "Astor 2010 Pops", on lollipops. ${ }^{13}$ The mark is a registered trademark and depicts the South African national flag in the zero numerals contained in "2010", and the get-up of the lollipops further contains soccer balls depicted on the background to the device. Metcash claimed to have used the "Astor" trademark since 1985 in respect of the marketing of its goods, which mark was claimed to enjoy a substantial reputation in the market place. ${ }^{114}$

FIFA applied for the following orders:

- To restrain the Respondent from infringing its registered trademark (to the "South Africa 2010 Bid \& Device") ${ }^{115}$ by making unauthorized use, in the course of trade, of the mark "2010 Pops" and/or "2010" in conjunction with depictions of the South African flag and/or depictions of soccer balls in relation to the product;

- to restrain the Respondent from passing its products off as being those of FIFA or as being products made under licence, or as being connected or associated with FIFA or with the 2010 World Cup; and

- to restrain the Respondent from competing unlawfully with FIFA by contravening section 15A of the Merchandise Marks Act, 1941, and/or section 9(d) of the Trade Practices Act, 1976.

FIFA's claims therefore related to whether the Respondent's conduct constituted a statutory trademark infringement in terms of section 34(1) of the Trade Marks Act, $1993,{ }^{116}$ whether such conduct constituted passing-off, or whether it constituted unlawful competition in contravention of the Merchandise Marks and Trade Practices Acts (that is, the standard causes of action as per the template for civil actions against potential ambushmarketers as developed by FIFA and its local legal representatives as an integral part of its anti-ambush marketing strategy).

FIFA claimed that its World Cup tournaments have received significant publicity and public interest in South Africa and that, as a result of an enormous repute and goodwill in the 2010 event, there are "strong common law-rights in that event", which vest in FIFA. ${ }^{118}$ As a result, FIFA claimed that the Respondent's use of its trademark and packaging would cause the general public to believe that there is some association between the Respondent's product and FIFA as the organizer of the 2010 event (that is,

\footnotetext{
112 The matter was argued on 12 December 2008, with judgment only being handed down on 1 October 2009.

${ }^{113}$ Federation Internationale de Football Association (FIFA) v Metcash Trading Africa (Pty) Ltd [2009] ZAGPPHC 123. My thanks to Deon Bouwer of Bouwers Inc, attorneys for the Respondent, for kindly providing me with copies of the parties' heads of argument and supporting documentation in this matter.

${ }_{114}$ Par 1 of the Respondent's heads of argument.

${ }^{115}$ Registered trademark number 2003/04015.

${ }^{116}$ Act 194 of 1993 . S 34 of the Act is referred to elsewhere in par 225 of Part 1 of this article.

${ }^{117}$ See the text to fn 129 in par 3 of Part 1 of this article, and the mention of the Eastwood Tavern litigation in the text above.

${ }^{118}$ Par 11.1 of the Applicant's heads of argument.
} 
"passing-off"). ${ }^{119}$ In respect of determination of the likelihood of deception or confusion with the public, FIFA argued that such confusion or deception can exist in members of the public believing that the Respondent's goods are endorsed by FIFA (that is, such as in cases of character merchandising). ${ }^{120}$

Metcash denied that its conduct constituted passing-off, mainly on the basis, firstly, that FIFA does not market lollipops and, secondly, that the law relating to passing-off provides that one may use offending marks if you clearly distinguish your goods from that of another. In this last respect, Metcash claimed that the "Astor" trademark clearly distinguishes its product from those of FIFA. FIFA, for its part, argued that the use of the "Astor" mark had no bearing on its contention that an impression of endorsement has been created (as it is only logical to assume that all licensees or sponsors of a sports tournament would use their own trademarks on the licensed products, as payment of the licence fee is done for the expected promotional gain to one's own marks), and that Metcash's first contention was irrelevant in light of the fact that a common field of activity is not required to prove passing-off.

In respect of the section 15A prohibition as contained in the Merchandise Marks Act, Metcash argued that proper recognition should be given to the difference in scope between the protection afforded by section 15(1) and section $15 \mathrm{~A}$ of the Act. It contended that section 15A merely restricts use of a trademark in respect of a protected event where such use is made in relation to the event, and to derive special promotional benefit from the event. According to its argument, this protection is less than that provided for in section 15(1), which allows the Minister of Trade and Industry to prohibit, either absolutely or conditionally, the use of the South African national flag or of any mark, word, letter or figure or any arrangement or combination thereof in connection with an event. ${ }^{22}$ Metcash referred to the fact that FIFA had earlier applied to the Minister for a blanket prohibition in terms of section $15(1)$ (b) of the Act of any use of "South Africa 2010" or of the depiction of a football "for any purpose and in any context other than use by [FIFA] or its mandatories", but that the Minister had refused to grant such a prohibition and instead restricted the terms of the prohibition so as to exclude the "South Africa 2010" emblem, the picture of a football and the word marks "South Africa 2010" and "SA 2010". ${ }^{123}$ This appears to be par for the course, as sports-governing bodies apparently prefer to take a "shotgun approach" in respect of requested protection, then settling for what they can manage to obtain.

\footnotetext{
${ }^{119}$ Par 15.2 of the Applicant's heads of argument.

${ }^{120}$ Par 17 of the Applicant's heads of argument.

121 Capital Estates and General Agencies (Pty) Ltd v Holiday Inns Inc 19772 SA 916 (A).

122 Par 26 et seq of the Respondent's heads of argument.

${ }^{123}$ Par 34 of the Respondent's heads of argument.

${ }^{124}$ Compare the London 2012 Olympics association right - Johnson explains how the Olympic contract between the IOC and host countries now requires the passing of legislation to "effectively reduce and sanction" ambushmarketing, and that the broad protection requested in respect of the London 2012 Olympic Games proved to be controversial and that the protection afforded in terms of the London Olympic Games and Paralympic Games Act, 2006 was considerably watered down from the original proposal (see Johnson 128-129).
} 
The prohibition which was published by the Minister was also qualified, in that it restricted the use of such marks only to "activities connected to the 2010 FIFA WORLD CUP SOUTH AFRICA in the area of FOOTBALL or SOCCER 2010 FIFA WORLD CUP". ${ }^{125}$ Accordingly, the Respondent's argument went that FIFA was seeking to rely on section 15A of the Act, which provides a lesser form of protection, to afford it protection which extends beyond the scope of the protection which it sought but failed to obtain in terms of section 15(1) of the Act.

Metcash denied claims that the mark connotes a formal connection with the 2010 FIFA World Cup event and constitutes ambush-marketing. It argued that the football connotation of the "Astor" mark relates to a football development programme for under-privileged youths, which it had launched in 2005 at the same time as its "2010 Pops" confectionery (and that the "2010" reference was included to refer to the year when such initiative is planned to terminate). ${ }^{126}$ FIFA denied such alleged significance of the reference to the year 2010, as it claimed that this was not publicized in Metcash's promotional material.

In a similar vein, Metcash argued that its conduct does not fall foul of section 9(d) of the Trade Practices Act, as its lollipops are marketed with reliance on its well-known "Astor" mark in a market place within which its association with football is well known, and accordingly its usage of the mark cannot be said to imply or suggest a contractual or other connection or association with the 2010 event. Metcash further argued that FIFA's assertion that any reference to "South Africa" and the year 2010 creates a connotation of the sort proscribed in section 9(d) was not backed up with any evidence.

Metcash further argued that section 15A of the Merchandise Marks Act must be read in light of the Constitution, and that the restriction on the use of their trademark (which was registered in 2004, prior to the date that the 2010 event was declared a protected event) violated Metcash's right of property ${ }^{127}$ in respect of its trademark as well as its freedom of expression. ${ }^{128}$ With reference to the courts' method of statutory interpretation in light of the Constitution $^{129}$ (which requires that, in the event of competing interpretations, a court must read down a statute so as to ensure an interpretation consistent with the Constitution), Metcash argued that a proper interpretation of section $15 \mathrm{~A}$ as only prohibiting use of a trademark which is unfair and likely to result in material harm to FIFA's marks would constitute a justifiable limitation of its rights under section 36 of the Bill of Rights. ${ }^{130}$ However, Metcash contended

${ }^{125}$ Par 35 of the Respondent's heads of argument.

${ }^{126}$ Par 2 et seq of the Respondent's heads of argument.

${ }^{127}$ In terms of $\mathrm{s} 25$ of the Bill of Rights.

${ }^{128}$ In terms of $\mathrm{S} 16$ of the Bill of Rights.

${ }^{129}$ With reference to Govender v Minister of Safety and Security 20014 SA 273 (SCA); and S v Coetzee 1997 3 SA 527 (CC).

${ }^{130}$ The limitation clause, which provides as follows:

"S 36(1) The rights in the Bill of Rights may be limited only in terms of law of general application to the extent that the limitation is reasonable and justifiable in an open and democratic society based on human dignity, equality and freedom, taking into account all relevant factors, including:

(a) the nature of the right; 
that FIFA's "broad and limitless" interpretation of the section's prohibition limits its rights "in an extremely invasive manner which could not ... be justified on any limitations exercise". ${ }^{131}$ In terms of the provisions of the Bill of Rights, FIFA bears the onus to prove justification of any limitation of Metcash's fundamental rights, which Metcash contended it had failed to do.

The hearing of the matter was argued on the basis of the third prong of FIFA's claim (namely that Metcash's conduct constituted unlawful competition in light of alleged contravention of section $15 \mathrm{~A}$ of the Merchandise Marks Act), and the issue to be determined was held to be whether Metcash had contravened the section of the Act. ${ }^{132}$

After a 10-month wait, Msimeki $\mathrm{J}$ ruled on the application on 1 October 2009 , in what can in this observer's view only be characterized (respectfully) as a rather disappointingly superficial judgment. The court held that Metcash had contravened section $15 \mathrm{~A}(2)$ and ordered that Metcash be "restrained from competing unlawfully" with FIFA. One aspect of the learned judge's order which the author finds particularly disappointing concerns the circular reasoning contained in FIFA's anti-ambushing strategy, which was referred to in the discussion earlier in this paper. FIFA's contention that a contravention of section $15 \mathrm{~A}$ should lead to an automatic finding of unlawful competition against Metcash was accepted without more (with the words that FIFA's contention in this regard "has merit"). ${ }^{133}$ FIFA's following contention also found favour with the Court:

"[R]egard must be had to the fact that licensees and sponsors of a world cup tournament use their own trade marks on the licensed products to promote their own trade marks and businesses. The examples are: MTN, FNB and TELKOM. The use of its trade mark by the Respondent, according to the Applicant, shows that it intended its pops to be associated with soccer and 2010 soccer world cup. If the Respondent had only intended its pops to be associated with soccer only, then the need would not have been there to mention 2010 world cup" ${ }^{\text {"14 }}$ (author's own emphasis).

The Court's acceptance of this contention, ${ }^{135}$ without more, is quite interesting in light of the fact that (in respect of the section in italics above) Metcash's get-up of the lollipops did not in fact include a reference to the "2010 World Cup", aside from the use of the numerals "2010" and a stylized depiction of the South African flag. FIFA had argued that Metcash's "selling of confectionery products under the trademark 2010 pops coupled with the

(b) the importance of the purpose of the limitation;

(c) the nature and extent of the limitation;

(d) the relation between the limitation and its purpose; and

(e) less restrictive means to achieve the purpose.

(2) Except as provided in subsection (1) or in any other provision of the Constitution, no law may limit any right entrenched in the Bill of Rights."

131 Par 45 of Respondent's heads of argument.

${ }^{132}$ Par 3 of the court's order (by Msimeki J, dated 1 October 2009 - unreported). Roshana Kelbrick on the afro-ip blogspot http://afro-ip.blogspot.com (accessed 2010-04-09) has suggested that the other two grounds of FIFA's claim, which were "not necessarily abandoned", would appear "more tenuous than generally admitted" in FIFA press reports.

${ }^{133}$ Par 7 of the court's order.

${ }^{134}$ Par 8 of the court's order.

135 Ibid. 
partial depiction of the South African flag and depictions of soccer balls ('the offending marks') ... constitute unlawful competition in that [Metcash] is thereby contravening section 15A of the MMA". The court accepted FIFA's contention that, in the event of such conduct being contrary to this provision, it would amount to unlawful competition. Nowhere is mention made of the fact that neither the (partial depiction of) the South African flag nor depictions of soccer balls are protected marks in respect of the World Cup; nor is it explained why soccer balls and the South African flag appear to have been held to allude to the 2010 World Cup.

It is, in my view, a pity that the court did not feel the need to consider, more fundamentally, the potential problems with the reach of the provision as contained in section $15 \mathrm{~A}(2)$, even though Metcash's arguments did raise the interpretation of the section and what its restrictions amount to. The following was said by the judge regarding the gist of the matter before the court:

"The nub of the matter, is whether [Metcash's] conduct is calculated to achieve publicity for the trade mark which results in the deriving of special promotional benefit from the event without the prior authority of the organizer of the event. If the answer is yes, then the conduct is unlawful, as [FIFA] submitted, irrespective of any damage to the 'trade mark' of [FIFA]. I agree."

While it is of course correct that a contravention of section $15 \mathrm{~A}(2)$ amounts to unlawful conduct, this unqualified acceptance of FIFA's submission is rather disappointing. While, as has been shown, section $15 \mathrm{~A}(2)$ does not require FIFA to show "damage" or that Metcash's conduct infringed a FIFA trademark, it is doubtful whether the absence of these elements should justify a finding that contravention of the section constitutes unlawful competition with FIFA and its sponsors and licensees.

In short, and in my view, the main objections to the judgment of the court is its lack of reasons and its failure to engage with the possible challenges to the legitimacy of the statutory provision beyond simply enquiring whether Metcash's conduct contravened the provision. With all due respect, the judgment reads like a mere rubber-stamping of FIFA's arguments by the learned judge, apparently without proper consideration (and explanation for the rejection) of Metcash's arguments relating to the manner in which FIFA was attempting to enforce the provision and that it was attempting to achieve protection that it was not legally entitled to in light of the Minister's earlier decision regarding protected marks for the 2010 event. Kelbrick has also expressed disappointment in the court's failure to engage with the constitutional arguments raised by Metcash, with reference to the elements of the section-36 limitations test as set out in the Bill of Rights. ${ }^{137}$

${ }^{136}$ Par 11 of the court's order.

${ }^{137}$ Roshana Kelbrick on the afro-ip blogspot http://afro-ip.blogspot.com (accessed 2010-04-09): "[Msimeki J] unfortunately gave no further consideration to the question of whether $\mathrm{s}$ $15 \mathrm{~A}$ is unconstitutional. This is a pity. The limitations contained in s 36 of the Constitution include the nature of the right (all holders of SA trade marks: here [on the FIFA $v$ Metcash facts], a trade mark used from 2004, two years before the s 15A prohibition commenced); the importance of the purpose of the limitation (for FIFA, through sponsors and licensees, to make money); the nature and extent of the limitation ( 4.5 years absolute prohibition); the relation between the limitation and the purpose 
At the time of writing, another matter relating to alleged ambush-marketing in respect of the 2010 World Cup is currently pending in the Gauteng North High Court, ${ }^{138}$ where it had been set down for a hearing on the merits ${ }^{139}$ on 23 April 2010) ${ }^{140}$ but has since been withdrawn from the roll by FIFA and has not been re-enrolled at the time of writing. This matter, which promises to provide the first meaningful consideration of the legitimacy of FIFA's claims for protection in terms of its litigation template (even if judgment is only expected to be handed down after the conclusion of the 2010 World Cup event), involves an application by FIFA against a Cape Town entrepreneur, Mr Grant Abrahamse, whose business, Executive African Trading CC, is the registered rights holder in respect of the shape and configuration (of the outline of) a keychain in the shape of a vuvuzela ${ }^{141}$ with the numerals "2010" superimposed on it (which design was registered roughly six months after South Africa was awarded the 2010 bid in 2004).

I am regrettably not able to include further discussion of this matter and its outcome at the time of writing, as it is believed (or hoped) that this case will bring much-needed clarity to our law in respect of the issues discussed in this paper. Ironically, it is expected that if the matter is not settled at such late stage (which currently appears extremely unlikely), judgment will only be handed down well after FIFA has quit our shores and proceeded to shift its focus to the playing fields of Brazil in 2014. Hopefully, the South African court will in fact deal fully with the many issues which have to be debated and such judgment may eventually prove to hold something of value to future hosts of the football world cup or may provide some guidance in respect of the reach of the anti-ambush marketing legislation for purposes of possible future events to be hosted in South Africa.

(there was a mere allegation that the staging of the event is in the public interest and no evidence was submitted that the organisers have created sufficient opportunities for small businesses and in particular those of the previously disadvantaged communities, in fact media coverage suggests the contrary); and less restrictive means to achieve the purpose (no equivalent relief is available in terms of any other legislation or common law - the provision is extraordinarily wide and no equivalent relief is available in terms of any other legislation or common law - for example trade mark rights are much narrower in scope and the applicant's registered trade mark does not give any such protection because of the disclaimers."

${ }^{138}$ Federation Internationale de Football Associations (FIFA) v Executive African Trading (EAT) CC Case No. 52308/07.

139 The High Court made a ruling in favour of FIFA on procedural issues relating to FIFA's application in October 2008, and the respondent's appeal against such ruling was overturned in June 2009

140 The court papers filed by the parties in this matter run to more than 550 pages, and Respondent's contention that oral argument in the matter will likely take up more than a single court day has necessitated a court date later than the originally scheduled hearing date of 24 March 2010.

141 The iconic, mass-produced local plastic trumpet which South African football supporters love to blow at football matches and which promises to be an enduring element of the legacy of (good or bad) World Cup memories for foreign visitors to the 2010 event (interestingly, FIFA reportedly received numerous complaints about the noise levels created by vuvuzelas at the 2009 FIFA Confederations Cup event, but the organization has ruled that the vuvuzela will not be banned from the 2010 World Cup, despite the findings of recent research that the noise levels created by the vuvuzela are potentially harmful and may cause permanent hearing loss). 


\section{THE EVOLUTION OF A POTENTIAL "SPORTS EVENT ORGANIZER'S RIGHT": SOME CONCERNS FOR THE FUTURE?}

As has been mentioned in the first part of this paper, and similar to the position in other jurisdictions (notably the UK, Australia ${ }^{142}$ and Canada ${ }^{143}$ ), South African law does not recognize a proprietary right to a sports event. In the words of Latham CJ in the Australian High Court, a "spectacle' cannot be "owned" in any ordinary sense of the word". ${ }^{144}$ While such a right to a sports event which is worthy and capable of protection against misappropriation appears to enjoy some recognition in the United Sates of America, ${ }^{45}$ in South Africa the rights to broadcast a sporting event or to disseminate news regarding the results and action on the field of play must be protected by means of other mechanisms and/or through a combination of other, recognized, legal rights. While this position has not been challenged in South African law to date, recent developments elsewhere bear scrutiny in light of the inter-related and significantly globalized nature of the international (professional) sports industry.

In terms of developments in Europe, and especially France, sports organizations have in recent times increasingly claimed what amounts to a "right to offer bets" in the sports gambling arena. Apart from claims based on trademark infringement and database rights to prevent third parties from offering bets on events, or systems of direct taxation from betting activities for re-investment in the sport, it appears that there have also been claims to an exclusive right to commercial utilization of (what appears to be) virtually all down-stream spin-offs of the events organized by such organizations. ${ }^{146}$ While, as mentioned, these developments relate to gambling on sports events and are indicative of an example of sports organizations having apparently identified a largely untapped potential source of revenue, this last claim raises interesting questions regarding the more general commercial monopolization of events, also in the anti-ambush marketing context.

In France, Article L333-1 of the Code du Sport ${ }^{147}$ provides for a "droit d' exploitation" for sports federations in respect of the events they organize,

142 Compare Victoria Park Racing and Recreation Grounds Co Ltd v Taylor (1937) C.L.R. 479; and Australian Broadcasting Corp v Lenah (2001) 208 C.L.R. 199. See also Wise "A 'Property Right' in a Sports Event: Views of Different Jurisdictions" 1996 4(3) Sport and the Law Journal 63.

${ }^{143}$ See National Hockey League $v$ Pepsi-Cola Canada (1995) 122 DLR $\left(4^{\text {th }}\right) 412$.

144 Victoria Park Racing supra 497 (a case where the owner of a residential property adjacent to the plaintiff's racecourse allowed a radio broadcaster to erect a scaffolding tower on his front lawn, from where the broadcaster could view races and broadcast commentary).

145 On the basis of the US Supreme Court judgment in International News Service $v$ Associated Press 248 US 215, 63 L Ed 211, 39 S Ct 68 (1918); Pittsburgh Athletic Co v KQV Broadcasting Co 24 F Supp 490 (WD Pa 1937); see also the judgment of the court of first instance in National Basketball Association and NBA Properties Inc v Sports Team Analysis and Tracking Systems Inc 939 F Supp. 107 (SDNY 3 September 1996) (overturned on appeal by the Second Circuit Court of Appeals in New York - 105 F 3d 841 (2d Cir 1997)); and Lewis and Taylor 405, 583 and 679; and Johnson 2-3.

${ }^{146}$ See Rohsler and Baudriller "Creation of a 'Right to Offer Bets': Analysis" 20097 World Sports Law Report 10-11.

${ }^{147}$ Law 84-610 (16 June 1984). 
and provides that "[s]ports federations and organizers of sporting events ... own the right to exploit sporting events they organize". ${ }^{48}$ Article L333-1 provides such event organizers with the right to license audiovisual exploitation of events, ${ }^{149}$ although recent case law has suggested that this monopoly to an event may have further reach than merely relating to sound and image rights. ${ }^{150}$ In light of these provisions, the rules and regulations of events organized in France will often expressly reserve rights granted in terms of the Code in grant of rights provisions. ${ }^{15}$

In 2009 the courts in France and Belgium saw litigation relating to betting on the "Roland Garros" tennis tournament, when the French Tennis Federation (or $\mathrm{FFT}^{152}$ ) sued betting operators Ladbrokes (in summary proceedings before the Liege courts in Belgium) and Unibet and Expeckt (in a suit on the merits before the Paris court of first instance). The Liege court dismissed the claim on the basis that unauthorized betting in respect of the event did not constitute a "tortuous act", as the FFT had claimed. The federation was more successful in the Paris court, where it was held that, even though the defendants' conduct did not constitute a trademark infringement in respect of the FFT's trademark in respect of the "Roland Garros" event, the FFT's monopoly in terms of Article L333-1 of the Code extended to downstream markets such as the organization of sports betting and that the unauthorized betting activity infringed on the federation's monopoly right, as well as constituting free-riding on the tournament's success which it was held constituted the tortuous act of parasitism. ${ }^{153}$ The Paris Court of Appeal confirmed the judgment of the court of first instance in October 2009, when it upheld both the findings of infringement of FFT's

148 "Les fédérations sportives, ainsi que les organisateurs de manifestations sportives ... sont propriétaires du droit d'exploitation des manifestations ou compétitions sportives qu'ils organisent."

${ }^{149}$ Which is further regulated in Articles $L$ 333-2 to $L$ 333-5 and Article $R 333$.

150 See $A C O$ and ASAACO vs. Dragoon Editions, CCE Tribunal de Commerce de Nanterre, 12 December 2002, implicitly confirmed in FFT vs Hospitality Group Tribunal de Grande Instance of Paris, 28 January 2004 (see Kobel "International Report on Question B: Ambush Marketing Too Smart to Be Good? Should Certain Ambush Marketing Practices Be Declared Illegal and If Yes, Which Ones and Under What Conditions?" 2007 International Report to the International League of Competition Law Catania Congress 19); and see also discussion of the FFT/Unibet matter in the text below.

151 See, eg, the Supplementary Regulations of the Le Mans 24-Hour event held in April 2009 where the provision dealing with the royalty-free granting of image rights/rights to sound recordings by competitors to the organizer, Automobile Club de l'Ouest (or ACO), contained a specific proviso that "It]he authorization of use of the Images and Sounds granted by the Competitor hereby is fully and totally independent from the ACO's right to operate the events and sporting contests it organizes, in accordance with Article L. 333-1 of the French Sport Code".

${ }^{152}$ Fédération Française du Tennis.

${ }^{153}$ In the judgment of the President of the court in the Tribunal de Grande Instance de Paris, 30 May 2008. The tort of parasitism has been described as follows:

"The French jurisprudence created a parasitism doctrine on the basis of public liability principles. The theory of parasitism is applicable to whoever takes advantage of another's representation without authorisation. It is applicable even if the victim is not a competitor. The reputation of the sport event itself is apparently protected. That theory was successfully applied in several sports related cases."

Kobel 2007 International Report to the International League of Competition Law Catania Congress 32 . 
monopoly rights as well as the finding of parasitism, as well as overturning the finding of the court of first instance by holding that Unibet's activities had also constituted a trademark infringement. The Court of Appeal awarded significant damages against Unibet of 300000 euros in respect of the trademark infringement, 400000 euros in respect of infringement of the FFT's exclusive right of exploitation and 500000 euros in respect of the parasitism claim. ${ }^{54}$ It was subsequently reported that the French government is pursuing a legislative amendment to broaden the scope of the exclusive exploitation right contained in Article L333-1 to the extent of providing sports federations with a right to charge betting operators for organizing betting on matches, amidst reports of Malta-based Unibet's intention to appeal the case to the European Court of Justice.

It is submitted that, in light of the concerns that have been expressed earlier in this paper, it is a potentially dangerous contention to allow for such robust protection of commercial rights to a sports event. It should be clear that the process of awarding exclusive sponsorship and other commercial rights to events - often for a long term and through a bidding process that appears to be very significantly skewed in favour of only the largest multinational commercial players - is not unproblematic, even when the commercial rationales of a need to generate substantial revenues in order to host large events and a need for exclusivity of rights in order to attract sponsors are often touted. As has been shown, such practices are not unproblematic in respect of their potential competition law implications. When viewed in light of the value and role of sport as a social activity (and even considering aspects such as the nation-building role of sport, as is so often emphasized in the South African context), coupled with the traditional notion of the trusteeship of sport as the basis for the very authority and powers that sports governing bodies wield, it becomes apparent that further and critical consideration of the legitimacy of such practices is required. One must consider the potential implications, if such an "event organiser's right" were to find its way into international sports-governance practice and the event organizer's anti-ambush marketing arsenal (that is, also in respect of the operations of governing bodies and the hosting of events in jurisdictions that do not recognize proprietary rights to events), especially bearing in mind that sports-governing bodies already appear to habitually flex their considerable economic muscle vis a vis governments in the bidding process to host major events. At the time of writing, not surprisingly, FIFA is hard at work behind the scenes in procuring legislative protection against ambushmarketing for purposes of the 2014 World Cup in Brazil; true to form, such proposed protections are extensive and ambitious indeed. ${ }^{155}$

${ }^{154}$ The judgment of the Cour d'appel de Paris, 14 October 2009.

155 Senate Bill 394 was presented on 3 September 2009, which deals with the 2014 World Cup and the 2013 Confederations Cup, and proposes provisions regarding the following:

- That FIFA owns the rights related to WORLD CUP 2014 and CONFEDERATIONS CUP 2013, including all the media, marketing, licensing and tickets;

- That FIFA and its licensees have exclusive rights to use a large number of terms, as well as combinations and similar terms, including: "Copa do Mundo da FIFA Brasil 2014", "Copa do Mundo da FIFA 2014", "Copa do Mundo da FIFA", "Copa do Mundo de Futebol", "Copa do Mundo", "Copa do Mundo de 2014", "Copa do Mundo do Brasil", "Copa de 2014", "Copa 2014", "Copa", "Brasil 2014", "BRA 2014", "BR 2014" and "Copa das Confederações da FIFA Brasil 2013"; 


\section{CONCLUSION}

As has been shown in this paper, the specific anti-ambush marketing legislation adopted in South Africa goes well beyond the reach of traditional intellectual-property rights protection (amounting to an example of what Johnson calls "IP+" protection), as well as going beyond the protection offered to event organizers by common law unlawful competition and passing-off actions.

Section 15A(2) of the Merchandise Marks Act envisages unlawful use of a mark to be its use "in relation to an event" that is "calculated to achieve publicity for such mark" (that is, one of the normal functions of the use of a trademark) and which thereby "derives special promotional benefit from the event", without the prior authority of the event organizer. In this context, it is important to consider what constitutes use in relation to an event, specifically in light of the fact that the Minister of Trade and Industry qualified the prohibition on the use of certain marks (which prohibition was, in any event, narrower than what FIFA had applied for in terms of section 15(1)(b) of the Act) to apply only to "activities connected to 2010 FIFA World Cup SOUTH AFRICA in the area of Football or Soccer 2010 FIFA World Cup". ${ }^{56}$ A wide interpretation of use "in relation to an event" would simply cast the net too wide and be too restrictive of the rights of trademark holders to employ their marks in the course of trade. Compare the judgment of Msimeki $\mathrm{J}$ in the Metcash matter, where it was held that "a proper consideration of the offending marks seem to confirm" that the World Cup event was "in the Respondent's mind" when the Astor mark was developed. It appears that use of the "2010" numeral in conjunction with the South African flag and soccer balls - none of which are prohibited marks in terms of the Minister's decision - was sufficient for the learned judge to consider such use to be in relation to the event and also calculated to achieve publicity for the mark which derives special promotional benefit for the mark. While I shall not express an opinion on whether or not Metcash in fact intended to ride on the coat-tails of the event (it is a fair assumption that this was indeed the case),

- That the names, flags, logos, anthems, trademarks and symbols of the national football organizations and teams, as well as the names and nicknames of athletes, are the exclusive property of those entities and enjoy national protection without the need for registration; and

- That the Brazilian Soccer Confederation (Confederação Brasileira de Futebol) and its sponsors have exclusive use rights over the following names until 30 days after the event: "SELEÇÃO BRASILEIRA", "SELEÇÃO", "SELEÇÃO CANARINHO", "EQUIPE BRASILEIRA DE FUTEBOL", "EQUIPE BRASILEIRA" and "EQUIPE CANARINHO". The Bill further prohibits goods, services and marks from being associated with protected names, flags, anthems, marks, logos and symbols. "Association" is defined as any use of the protected symbols, regardless of whether such use is unintentional or disclaimers such as "non-authorized" or "unofficial" are used. The only exceptions are not-for-profit use by natural persons and use exclusively for information, critique or opinion by media outlets, including online, without association with an unauthorized natural person or company. In addition, there is a "grandfather provision" respecting rights registered before the law comes into force. The Bill also establishes "clean zones", where any form of commerce, advertising, marketing or publicity not authorized by FIFA is prohibited - from a report by Rodrigo Borges Carneiro "Comparative advertising and ambush marketing on the rise in Brazil" December/January 2010 World Trademark Review 52-53.

${ }^{156}$ GN 1791 in GG 30595 of 2007-12-14. 
it is submitted that the learned judge's wide interpretation regarding the elements of abusive use as contained in section 15A may not have been justified on the evidence and with reference to the offending mark under evaluation. ${ }^{157}$

And such a wide interpretation is dangerous, especially in light of the fact that, clearly, the prohibition regarding abusive use in section $15 \mathrm{~A}(2)$ could hit many instances of perfectly legitimate trading and use of a mark, specifically in instances of what is referred to as "intrusion ambushing" "158 (although one should note the pejorative implications of such term), which would otherwise, in the absence of this far-reaching provision, be completely unobjectionable and not actionable. Similar to the absence of qualification in the section in terms of the requirements for liability for trademark infringement, as mentioned above, the section also does not concern itself with the requirements for common-law liability for passing off, ${ }^{159}$ namely the "classical trinity of reputation (or goodwill), misrepresentation and damage". ${ }^{160}$ While such requirements will doubtless be satisfied in blatant association ambushes in respect of an event, the same is definitely not true of what may transpire in many (if not most) cases of so-called "intrusion ambushes".

For example, let's compare a fictional advertisement for a local beer which depicts the obligatory group of beautiful people (from different ethnic groups but the same relatively affluent social status, naturally) enjoying a few cold ones in front of the TV while watching football, with a slogan along the lines of "Ride the world cup wave - Celebrate with lager!", and which

${ }^{157}$ Kelbrick points to the dangers, in characterizing FIFA's extremely requests to the Minister of Trade \& Industry for protection in terms of section 15 of the MMA, as "attempted overreach": "To exclude everyone but FIFA and its mandatories from using words such as 'world cup' or numerals such as '2010' 'in connection with any trade, business, profession, occupation or event, or in connection with a trade mark, mark or trade description applied to goods' would be excessive. It would include a prohibition on use as a trade mark for goods and services. But, unlike registered trade marks, that are fenced in by the principle of specificity, the FIFA prohibition would apply to all goods and services. The words or symbols sought to be protected under the Merchandise Marks Act are not subject to the tests for registrability imposed by the Trade Marks Act ... Nor are they subject to the endorsements recorded against the same words or emblems registered under that Act ... Also, a prohibition in terms of section 15(1)(b) is not merely on use 'as a trade mark'. This provision is phrased in substantially wider language, and appears to prohibit any commercial use of these words or symbols."

Kelbrick "Ambush Marketing and the Protection of the Trade Marks of International Sports Organizations - A Comparative View" 2008 41(1) CILSA 2437.

${ }^{158}$ See the discussion in par 21 of part 1 of this article.

${ }^{159}$ Compare the generally accepted definition of the delict of passing-off was formulated as follows by the (then) Appellate Division in the case of Capital Estate and General Agencies (Pty) Ltd v Holiday Inns Inc 19772 SA 916 (A) 929:

"The wrong known as passing off consists in a representation by one person that his business (or merchandise, as the case may be) is that of another, or that it is associated with that of another, and, in order to determine whether a representation amounts to a passing off, one enquires whether there is a reasonable likelihood that members of the public may be confused into believing that the business of the one is, or is connected with, that of another ... Whether there is a reasonable likelihood of such confusion arising is, of course, a question of fact which will have to be determined in the light of the circumstances of each case."

${ }^{160}$ As per Harms JA in Caterham Car Sales and Coach Works Ltd v Birkin Cars (Pty) Ltd 1998 3 SA 938 (SCA). 
contains a very clear disclaimer that the beer producer is not an official sponsor of the World Cup event and is in no way associated with the event. Assuming that the beer maker's mark is not similar or identical to the registered mark of the event organizer or an official sponsor or likely to deceive or cause confusion in respect of such a registered mark, this advertisement would clearly not constitute a trademark infringement. Similarly, no copyright infringement would be at issue. Which leaves the question of whether the advertisement would constitute an attempt by the beer maker to represent its business or beer as that of the World Cup organizer or of its official sponsor(s), or that it is associated therewith. ${ }^{161}$ Our courts would determine the answer to this question by asking whether there is "a reasonable likelihood that members of the public may be confused into believing that the business of the one is, or is connected with, that of another" ${ }^{162}$ Clearly the (explicit) disclaimer ${ }^{163}$ would prevent such a finding, and the beer maker's conduct would not constitute passing-off. This is also true in terms of our courts' extended application of the passing-off action in respect of representations of false endorsement, ${ }^{164}$ which is also excluded by the disclaimer.

However, in terms of section 15A(2) of the Merchandise Marks Act, our beer maker will be in hot water, as it has, without the prior authority of the world's football governing body, used its own registered trademark (1) "in relation to" the World Cup event, in a manner (2) that is "calculated to achieve publicity for such mark" and which thereby - as FIFA would no doubt claim - (3) allows it to "derive special promotional benefit from the event". It appears to be a case of "three strikes you're out". And the disclaimer will not assist: as mentioned, section $15 \mathrm{~A}(2)$ does not require the representation of an association and a disclaimer of non-association will not exclude liability.

Our trader is a small family business, and the litigation fees and hefty fines for contravention of the Merchandise Marks Act force it out of business, and sees Bob the beer maker and his family, including the little ones, ending up on the street. It is hard to explain to Bob that his life has just been shattered in order to protect the exclusivity of a licensing arrangement

${ }^{161}$ In respect of the wording of the advertisement in this example: Despite FIFA's request for protection for the 2010 event in terms of section 15 of the Merchandise Marks Act (s 15(1)(b)) of certain commonplace words, including 'world cup', the Minister of Trade and Industry decided to only prohibit use of such words that include references to both FIFA and to soccer or football - see GN 1791 in GG 30595 of 2008-12-14; Kelbrick 2008 41(1) CILSA 37.

162 As per the Capital Estate case - see note 159 above.

${ }^{163}$ In respect of the use of disclaimers, Kelbrick (2008 41(1) CILSA 40) refers to the controversial presumption of guilt provision contained in $s 11$ of the New Zealand antiambush legislation, the Major Events Management Act 35 of 2007. This provision provides that a court may presume that a representation that is likely to suggest an association with a protected event is in breach of the Act if it includes a protected word or symbol, even if the representation is qualified by words like "unauthorized" or "unofficial".

${ }^{164}$ Compare the judgment in the character merchandising case of FIFA v Bartlett 19944 SA 722 (TPD), as discussed in par 225 in Part 1 of this article; see also the arguments regarding a misrepresentation of endorsement as advanced by the applicant in Federation Internationale de Football Association (FIFA) v Metcash Trading Africa (Pty) Ltd [2009] ZAGPPHC 123, as discussed elsewhere in this article. 
between FIFA and, let's say, Budweiser, ${ }^{165}$ an overseas-based "competitor" of Bob's whose product is not even sold in South Africa, ${ }^{166}$ but who paid tens of millions of dollars for an exclusive 10-year sponsorship arrangement in respect of the World Cup (which Bob never had the opportunity or means to bid for and would not have been successful in obtaining in any event). Bob is adamant that he only traded freely and with the use of his own intellectual property (his lawyer allegedly convinced him to spend thousands to register his trademark years before FIFA even decided to pack its bags and fly to South Africa in 2010) in a way that would appeal to potential consumers. Bob points out that one can hardly set foot out the door in South Africa without encountering "World Cup fever" or some reference to football, and that he only wanted to join the spirit of the masses in excitedly looking forward to FIFA's event, and to sell some beer in the process. In fact, and with some irony, Bob reminds you that FIFA chastised the South African government in 2009 for failing to promote the Confederations Cup (the dress rehearsal for the 2010 event) sufficiently aggressively, and enjoined it to gear up its efforts through even more extensive marketing campaigns. Finally Bob admits that he used his mark in a way that was calculated to achieve publicity for the mark, but insists that his lawyer informed him years ago that that is in fact what one does with a trademark. Bob does not seem to grasp the error of his ways and appears unrepentant, and at long last you leave in frustration to escape the wails of hungry children.

This might be a rather simplistic example, but it is hoped that the point has been made, that the South African anti-ambush marketing legislation which was passed under reported pressure on the government by one international sports governing body and has now been aggressively employed in order to protect the commercial arrangements between another such body and its commercial partners - is extremely extensive and goes far beyond the traditional protections offered to rights holders to protect them from unscrupulous merchandisers. And, it is submitted, FIFA's litigation strategy in respect of such legislation, which has been followed to date in this jurisdiction as discussed above, appears to have added insult to injury in respect of the unfortunate litigants who may end up on the other side of the courtroom. The respondent in the latest such matter (which is at the time of writing pending before the North Gauteng High Court), the holder of a design for a football-themed keychain, ${ }^{167}$ claims that he received a bill for licensing fees in the amount of ZAR 250000 per year as well as for $15 \%$ of the profits as royalties from FIFA in 2005 (this after FIFA allegedly refused to settle the dispute amicably and allegedly stated that they intended to make an example of him).

While such aggressive enforcement and strong legislative prohibitions may not seem overly problematic when viewed against the backdrop of what

${ }^{165}$ In the United States, Anheuser-Busch habitually ranks as the top sponsorship spender with annual paid rights fees in excess of USD 310 million - see Irwin, Sutton and McCarthy 148.

${ }^{166}$ It should be noted, of course, that contravention of $\mathrm{S} 15 \mathrm{~A}(2)$ of the Merchandise Marks Act does not require unlawful competition or that an actual or potential competitor has been prejudiced by the defendant's conduct.

167 See discussion of FIFA v Executive Africa Trading in par 4 above.

${ }^{168}$ See the report by Seale "FIFA are Bullies" web site of Independent Online Newspapers http://www.iol.co.za (accessed 2010-04-12). 
has been experienced in other jurisdictions in recent times in respect of blatant association ambush-marketing, it should be remembered that association ambushes would usually in any event constitute unlawful conduct that is prohibited in terms of either the common law or specific (for example, IP) legislation, and which can (should?) be pursued in terms of such remedies. Scaria, in discussing potential competition law issues in respect of anti-ambush marketing protection, observes as follows:

"[E]ven the pro-competition bloc would appreciate the [anti-ambush marketing] restrictions which seem reasonable in light of the economic investments made by the sponsors and in the necessity of defending the sponsorship value of an event. It is also essential not to overlook the very fact that most of the sponsorship contracts are awarded through a process of open bidding. Moreover, competition law by itself permits restrictions on false and misleading advertisements ... If ambush marketing advertisements are considered as misleading advertisements, the regulations on such advertisements shall not fall within the purview of competition law."

I have no objections to special anti-ambushing legislation to enforce existing common law protections, with the objective of addressing the practical hurdles posed by such traditional protection (for example, the need for speedy procedures when faced with a major event with a limited window of exploitation in respect of association ambushing). The situation assumes a very different aspect, however, when one considers the fact that what may be termed "intrusion ambushes" of events do not, necessarily, raise any concerns regarding the ethics or legality of the alleged "ambusher's" conduct. A marketer can surely run a very successful marketing campaign through reference to a major event without actually deceiving (or even attempting to deceive) the public regarding an association with such event.

By no means am I advocating the practice of "intrusion ambushing" - if I have to watch one more football-themed advertisement relating to the 2010 World Cup, I might be physically ill. However, I am in favour of "intrusion ambushers" freedom to trade by producing such ads. The above consideration coupled with the severe - and yes, I will pointedly use the word "draconian" - limitations on the rights and freedoms of individuals, business entities and entrepreneurs, forces one to ask whether such legislation does not in fact constitute an abomination of the very values and ideals underlying our developmental state and constitutional democracy. Events during the early days of the 2010 football World Cup (in the week of 14 June 2010) made headlines worldwide and promised a potential diplomatic row between the Netherlands and South Africa, when FIFA filed criminal charges against two Dutch nationals in the country over an alleged ambush-marketing campaign by Dutch beer maker Bavaria NV. ${ }^{170}$ According to reports, Bavaria allegedly sent two Dutch nationals to South Africa to recruit (through a local promotions company) 36 young ladies, who attended

${ }^{169}$ Scaria Game Within a Game (2008) 118.

170 During the previous World Cup in Germany in 2006, a similar episode occurred when approximately a thousand male fans who were clothed in orange lederhosen - also, reportedly, supplied by Bavaria - were asked to strip out of the outfits or leave the stadium during a Netherlands/Ghana match. A number of the fans reportedly stayed to watch the match in their underwear. 
the first-round match between the Netherlands and Denmark in Soccer City in Johannesburg as a group wearing orange "Dutchy" dresses (which had been handed out in Bavaria gift packs in Holland ahead of the World Cup) bearing Bavaria's logo on a small purple tag on the side near the hemline. The women were reportedly escorted from the stadium by security staff during the second half of the match and, allegedly, interrogated by FIFA officials for three hours at nearby FIFA offices. The two Dutch women were subsequently arrested on charges of contravening the Merchandise Marks Act and provisions of the 2010 FIFA World Cup South Africa Special Measures Act, ${ }^{171}$ and released on bail (pending trial in the Johannesburg Magistrates Court's "special FIFA World Cup court"). It was reported at the time that the women had instructed a local firm of attorneys and were contemplating legal action against FIFA and the police, alleging that they were warned not to run as they might get shot, and that their hotel room was allegedly searched without a warrant and that personal items were taken. ${ }^{172}$ The Netherlands government slammed the conduct of FIFA and of the SA Police Services for singling out the Dutch nationals and also for proceeding against the individuals involved rather than against Bavaria, with Dutch Foreign Minister Maxime Verhagen characterizing the arrests as "disproportionate and not correct". FIFA responded by reiterating its aggressive anti-ambush marketing stance and by stating that it had warned businesses prior to the event that it would clamp down on any attempts to ambush the event. While, at least according to reports, it appears that these events stemmed from a concerted and well-planned marketing campaign by Bavaria, it is submitted that they highlight the potential for rather absurd results through the confluence of anti-ambushing legislation such as that found in South Africa and the attitude of an organization like FIFA to its aggressive enforcement. In years gone by an episode of this nature would have prompted little more than a chuckle from right-minded persons and a small measure of admiration for a creative and colourful marketing campaign that added some spice to a major sporting event and its hype (especially at a time when the quality of football on the pitch during the opening round of the tournament had been rather disappointing). In this day and age, however, it appears that the colour of one's dress could augur a lengthy jail term; one might be forced to exchange an orange mini-skirt for an orange prison jumpsuit because Budweiser has a contract with FIFA. After vocal outrage from a number of sources following media reports of the criminal case against the two Dutch nationals, it was announced on 23 June 2010 that the National Prosecuting Authority had decided to abandon the prosecution, as FIFA had reportedly reached a settlement in the matter and 'had no further interest' in the prosecution of those involved. It appears that the events were belatedly recognized as a rather embarrassing publicity faux pas for the football governing body and South African prosecuting authorities, and was probably dropped for that reason.

${ }^{171}$ The women were apparently charged with engaging in "unauthorised commercial activities inside an exclusion zone" and "enter[ing] into a designated area while in unauthorized possession of a commercial object".

172 From a report in Afrikaans newspaper Beeld, 18 June 2010. 
It is submitted that there exists a very real (and, in my opinion, already realized) danger that legislature's bowing under what amounts to legalized extortion in respect of the enactment of legislative protections for what sports governing bodies claim as their own, simply serves to increase the demands of these same bodies to wider and wider protection. Johnson is of the view that this is indeed already the case (in respect of his criticism of "vertical and horizontal creep" in the development of specific anti-ambushing legislation in different jurisdictions and in respect of different sporting events) ${ }^{173}$ and I would suggest that a fruitful analogy can be drawn to criticism that has been expressed elsewhere regarding the protection of celebrity by means of the right of publicity in the USA:

"Granting property rights in fame is a dangerous proposition in no small part because celebrities tend to be control freaks ... As their egos expand, so do their publicity rights. They conceive of their rights as granting them permission to ban any cultural expressions that tread on their alleged identity."

It is submitted that the time has come to say to the large international sports-governing bodies that they will no longer be allowed to derive a mandate from the sport-supporting public to host events that are dependent on the support of such public, but in the same breath attempt to monopolize any and all commercial opportunities arising from such events and restrict members of the public from deriving any benefit apart from access to the spectacle, for which they of course have to pay (sometimes exorbitant ticket prices). And, more emphatically, the law should not be allowed to be abused as a means of protecting and maintaining such monopolies whilst the base generation of profits for a powerful few appears to be its main objective. We might find some guidance in the approach suggested by the European Sponsorship Association: ${ }^{175}$

"[We recognise] that major sporting and other events are a key element of modern culture and it is wrong to give an event organiser a complete monopoly over any references or allusions to the event. Major events have to operate along the lines of commercial businesses in order to fund themselves, but they are also part of a shared set of human experiences in the public domain. Companies, brand owners and their representatives should be allowed to refer to such events, provided that (a) intellectual property rights are respected; (b) official status is not implied when none exists; and (c) the reference is not unlawful in some other way (e.g. libellous, in breach of contract etc)."

However, while this suggestion does, I believe, constitute an approach to which we should aspire, it appears that very few members of the legal community have to date bothered to engage with some of the more sticky issues regarding the legitimacy of anti-ambush marketing measures and practices. This appears to be true, especially, in respect of governments and legislatures in the different jurisdictions. It is beyond the scope of this paper to investigate the extent (if any) to which the South African government conducted an in-depth investigation into the pros and cons of adopting the relevant anti-ambush marketing legislation prior to the 2003 ICC Cricket

\footnotetext{
173 See, generally, Johnson 2008 2(3) International Sports Law Review 24-29.

174 Bollier Brand Name Bullies: The Quest to Own and Control Culture (2005) 135.

175 In its Position Statement on Ambush Marketing, 14 October 2005.
} 
World Cup or in the process (in terms of section 15A(1) of the MMA) of declaring the 2010 FIFA World Cup South Africa as a protected event. ${ }^{176}$ While the Minister of Trade and Industry may for all that I know be in possession of a lengthy report stating that the 2010 FIFA World Cup is "in the public interest and ... [that] the organizers have created sufficient opportunities for small businesses and in particular those of the previously disadvantaged communities" to benefit from the event, ${ }^{177}$ I would suggest that the curious reader might want to poll the opinions of the various taxi associations (who are currently protesting against government's unilateral imposition of the Bus Rapid Transit system in the run-up to FIFA's event), informal street traders and the homeless (who will be persona non grata in eight of our major cities come June/July this year) and the owners of pubs, restaurants and other establishments that are possibly facing stiff liquor license fees for a special dispensation to screen World Cup matches while their patrons knock back a few. An undated government publicity document on preparations for the 2010 World Cup (circa 2008) ${ }^{178}$ contains the following:

"Government aims for the [small and medium-sized enterprises] sector to benefit from the 2010 World Cup. The Department of Trade and Industry is supporting the SME sector to access economic benefits and opportunities brought by the 2010 FIFA World Cup ${ }^{\mathrm{TM}}$. Government negotiated that $30 \%$ of the budget of the Organising Committee should be allocated to Black Economic Empowerment and SMEs in terms of procurement policy."

In light of sustained criticism of the often mythical "broad-based" credentials of the Broad-based Black Economic Empowerment programme in respect of government procurement processes (and the nearly daily media reports on the activities of politically-connected "tenderpreneurs"), it is submitted that is doubtful whether the above initiative, in itself, satisfies the requirements for the designation of an event as "protected" in terms of section $15 \mathrm{~A}(1)(\mathrm{b})$ of the Merchandise Marks Act. Local readers will also recall the recent controversy following media reports in February 2010 that the contract to produce toy figurines of the official World Cup mascot, Zakumi, had been outsourced to a reported sweat shop in China. The local contractor who had been awarded the contract is an African National Congress (ruling party) member of Parliament (ironically, a member of

${ }^{176}$ With specific reference to the proviso contained in $\mathrm{S} 15 \mathrm{~A}(1)(\mathrm{b})$. Compare the following requirement for the declaration of a "major event" in terms of s 7(4) of New Zealand's Major Events Management Act 2007:

"(4) Before making a recommendation [to the Governor-General to declare an event as a major event], the Economic Development Minister must take into account whether the event will -

(a) attract a large number of international participants or spectators and therefore generate significant tourism opportunities for New Zealand;

(b) significantly raise New Zealand's international profile;

(c) require a high level of professional management and coordination;

(d) attract significant sponsorship and international media coverage;

(e) attract large numbers of New Zealanders as participants or spectators;

(f) offer substantial sporting, cultural, social, economic, or other benefits for New Zealand or New Zealanders."

${ }_{177}$ Merchandise Marks Act s 15A(1)(b).

${ }^{178}$ Key Facts: Government Preparations for the 2010 FIFA World Cup South Africa ${ }^{T M}$. 
Parliament's economic development committee - tasked with the creation of new workplaces in South Africa - whose parliamentary profile reads "We need more opportunities in order to bring more opportunities into the country"). ${ }^{19}$ It is suggested that the real experience of job creation and commercial opportunities for small and medium-sized enterprises in respect of the 2010 event has been largely illusive and, in this observer's opinion, does not play much of a role in tipping the scales in the determination of justification for the substantial limitations imposed on traders in terms of the anti-ambushing legislation. The interested reader is strongly advised to read a recently-released monograph published by the Institute for Security Studies regarding conflicts of interest and reported corruption regarding the 2010 FIFA World Cup, which makes for fascinating reading. ${ }^{180}$

In a 2007 ambush-marketing legislation review conducted for the Australian government ${ }^{181}$ the following was observed regarding the issues to be considered in respect of the passing of specific anti-ambush marketing legislation:

"Calls for legislative intervention in relation to sports and major event marketing generate two key questions:

\section{What types of ambush marketing should be regulated?}

This question involves the allocation of rights and the enforcement of rights. In allocating rights, there are clear trade-offs. As the set of rights allocated to the organisers of an event is widened, the set of rights allocated to other persons is narrowed. The government has to make a decision as to what might be a reasonable allocation of rights between different groups. The re-allocation and enforcement of rights may be a way of dealing with perceived problems of ambush marketing. However, governments need to consider whether the perceived problems justify the intervention, and whether legislation is the best option for addressing the problem. Other factors might also have a bearing on these questions, such as a host agreement in which an event's governing body requires certain protection of intellectual property and marketing activity for a country to stage an event.

\section{How should legislative intervention be crafted?}

Having identified that there is a need for legislation, the next stage is to determine the best way to respond to that need. The government has to decide, for instance: whether event-specific or general legislation would be more effective; the scope of the exclusive rights provided to the event organiser, including the range of subject matter protected; the limits of those exclusive rights, and the framing of any exemptions. The principal concern is in ensuring that provisions achieve their stated goals, but not in a way that unduly or unfairly affects the rights of third parties ... [D]espite its pejorative connotations, the term 'ambush marketing' is used to cover a broad range of activities that include practices that are perhaps rightly not the concern of the law or may not justify government regulation."

${ }^{179}$ From a report entitled "Zakumi, Proudly South African?" 3 February 2010 The Budapest Report.

${ }^{180}$ Schulz-Herzenberg 169 - at the time of writing this monograph is available as a free download from the website of the Institute for Security Studies http://www.iss.co.za.

${ }^{181}$ Frontier Economics Ambush Marketing Legislation Review October 2007 (Prepared for IP Australia and the Department of Communications, Information Technology and the Arts) 20 21. 
Ditto. I have touched on issues such as the constitutionality of antiambushing measures (in respect of, for example, guarantees of freedom of expression) and their potential anti-competitive impact, but little work has been done in this regard. For example, the following is found in a relatively recent multi-national survey on the combating of ambush-marketing, which covered a number of European and other jurisdictions:

"[The above-mentioned issues] are still relatively unexplored. Writings on ambush marketing are usually more driven towards fighting ambush marketing for the benefit of sport. Writings and decisions on antitrust issues have usually focused on issues pertaining to the transfer of players, collective bargaining of TV rights and a few abuse of dominance cases in relation to the exploitation of rights related to an event. None really focused on sponsoring activities and the exclusivity granted to sponsors. As a result, not much was reported on these issues in the surveyed countries."

It is sincerely hoped that much more attention will be paid to such matters, if only in order to introduce serious consideration of these issues into the mainstream of thinking in the major events-hosting bid processes. This might go some way towards guaranteeing more legal challenges in future to the (what I submit to be) largely unquestioned abuse of power by major sports federations and their pin-stripe-suited money men. At the very least, let's have some wider public consultation in future before any decisions are taken to bid for major events.

In the meantime, organizations like FIFA and the IOC appear to soldier on unfazed, vigorously demanding the protection of the law for their commercial monopolies in the jurisdictions where they encamp for a few weeks every four years. It is rather ironic to consider the apparent arrogance of these Swiss-based organizations, seeing that Switzerland itself does not have specific anti-ambush marketing legislation (such measures are apparently limited to the domain of unlawful competition) and, according to at least one report, ${ }^{183}$ there is a sentiment in that jurisdiction small businesses should have extensive freedom to capitalize from marketing around major events. ${ }^{184}$ In my opinion FIFA's arrogance and apathy towards the host nation and its people should be clear for all to see. Apart from its widely-reported and deep-seated Afro-pessimism regarding South Africa's ability to manage to build stadia and ensure that trains run on time to get fans to matches, the organization appears also to have had some concerns that mascot figurines manufactured in South Africa might decide to explode and kill a toddler (no such danger if the toy is produced in a Chinese sweat shop, of course) or that $\mathrm{Mr}$ Blatter might have to take a pay cut if they allow a vendor to sell boerewors rolls or bunny chows near a match venue. When FIFA

\footnotetext{
182 Kobel 2007 International Report to the International League of Competition Law 41. ${ }^{183}$ Ibid.

${ }^{184}$ Kobel 2007 International Report to the International League of Competition Law 54, observed the following regarding the relevant country reporters' views in respect of the sufficiency of anti-ambush marketing protection in Switzerland:

"The Swiss Reporters believe that unfair competition protection is sufficient to deal with ambush marketing practices. They also think that small and medium size enterprises cannot play the same game as big enterprises and therefore are de facto excluded from bidding. They should therefore be able to make reference to the event for economic advantage."
} 
commissioned a Hollywood-based events coordinator to organize the firstever "Kick Off Celebration" music concert scheduled for the evening before the opening match of the 2010 event, it appeared to feel that very few local musicians are good (or popular) enough for its showcase. After vocal protest by the local Creative Workers' Union (and suggestions voiced at a Cape Town musicians' conference for a free-admission "rebel" concert by local artists - which one industry member reportedly suggested should be called the "Fuck FIFA" concert ${ }^{185}$ ), FIFA magnanimously allowed more South African artists on the programme for its musical extravaganza. It is evident that FIFA's overriding concern was that its 2010 World Cup should produce a "cleansed" entertainment package for its European TV audiences; despite footing most of the bill, the "host nation" plays little role in what is ultimately a FIFA event. Ironic, then, to consider that South Africa's President in April 2010 honoured Sepp Blatter with the award of the Order of the Companions of OR Tambo (a medal given to foreigners for friendship shown to South Africa) for Blatter's "exceptional contribution to football" and support for the hosting of the World Cup in Africa.

It is submitted that the commercial monopolization of sporting events and the resultant aggressive pursuit of anti-ambush marketing protection constitutes an important although insufficiently considered example of the whittling away of the public domain as examined by some critics of the widespread abuse of intellectual property laws in recent times by large commercial actors such as multinational corporations. In essence, recent developments in anti-ambush marketing protection worldwide equates to the following:

Legislation has been passed in a number of jurisdictions in order to prohibit association ambushes - this is in line with the common law protections already in place against unlawful competition, passing-off and deceptive trade practices. Such legislation has in a number of instances, however, extended the protection of intellectual property beyond what IP law traditionally protects - the elements of deceptive use in terms of trademark law and the immunity of generic descriptions in terms of both trademark and copyright laws have apparently been abandoned by lawmakers in favour of all-encompassing protection against any form of association with events and event organizers, which have little foundation in accepted notions of law. The apparent trend towards the creation of association rights to events has gone beyond covering only "association ambushes" in light of the wide application of the relevant legislative prohibitions - these "rights" have apparently developed with no theoretical or jurisprudential underpinning. As shown in this paper, event organizers and their commercial partners hold no "property right to a spectacle" in respect of such events; by legally prohibiting an extremely wide and insufficiently explained "association" with an event which extends to mere reference to the event (even when coupled with clear

${ }^{185}$ During the playing of the 2010 football World Cup event there appeared to be a growing feeling of disillusionment and even anger at FIFA amongst South Africans. A Cape Town artist was reported as doing a brisk trade in "Fick Fufa" $t$-shirts as a non-profit venture. Local satirical news site Hayibo.com was also selling a range of t-shirts that lampooned FIFA's copyright and other IP rights to phrases and other things, with the logo "FEEFA 2.010 WHIRLED CUP SOWTH AFRIKA" - from a report by Raborife "Fick Fufa!" 18-24 June 2010 Mail \& Guardian. 
disclaimers of non-association) legislators have created unprecedented and illegitimate grounds for (criminal) liability of persons who are de facto not acting in contravention of established principles of law. Ironically, whilst there is a developing movement opposed to the abuse of traditional intellectual property laws, worldwide, the commercial monopolization of major sporting events and the legislative legitimization thereof in jurisdictions such as South Africa has added a worrying new dimension to the mix. In the professed name of the common good and the public interest, huge commercial interests and undemocratic monopolies engaged in the governance of international sport have been granted legal license to "strip-mine" the public domain and the public interest in what is one of the last remaining bastions of national and cultural pride in our globalized world - top-level international sporting competition. This state of affairs enjoys not only the positive protection of the law but is also frequently propped up by apparent immunity from both political scrutiny and legal prosecution. In this regard I shall leave the reader with the words of one of FIFA's most avid critics (who has gone so far as to liken the organization to the Mafia with reference to the accepted characteristics of organized crime):

"Legislators and public prosecutors have been cowed by FIFA's insistence that its affairs may not be meddled in by elected governments. Together with the IOC, FIFA claims 'autonomy' for sport with the thin argument that governments must not be permitted to interfere in the 'independence' of sports federations. The risible suggestion that these federations, so often tarnished by ballot rigging, corruption and ticket scandals, should be above the law, is accepted by most governments, most of the time."

It is submitted that the South African legal fraternity has a special obligation to engage critically with these issues, as our legislature has established, in the form of section 15A(2) of the Merchandise Marks Act, the most comprehensive and far-reaching anti-ambush marketing provision to be found anywhere $-\overline{187}$ a development that has already been blindly duplicated elsewhere. ${ }^{187}$

We are all - this author included - excited about hosting the world's biggest sporting event and the world's most talented footballers in a country that is so mad for the sport. However, developments such as those discussed in this paper leave a bitter taste, and when I view video footage of the infectious excitement of those present at that historic moment when FIFA's president announced that South Africa was successful in its bid to host the 2010 event, it brings to mind the well-known proverb: "Be careful what you wish for, as you may just get it."

Following the excitement of what was truly a hugely successful World Cup, it is sincerely hoped that the legacy of the event will be an enduring positive one which will deliver on what is essentially an once-in-a-lifetime opportunity for this country to showcase itself on the international stage. However, this spectacle has brought with it the worrying element of powerful

186 Jennings 91.

${ }^{187}$ Compare ss 25(2) and (3) of the ICC Cricket World Cup West Indies 2007 Act 28 of 2006, which was passed by the Parliament of the Republic of Trinidad and Tobago, 1 November 2006. The wording of the relevant sections of this Act is nearly identical to the South African ambush-marketing provisions referred to. 
commercial monopolies and disturbingly blatant displays of the rather paradoxical excesses of absolute power at the cost of the common good and individual freedoms, which I believe are inimical to the values underlying our constitutional democracy, our economic system and our system of laws. It is probably sad (and a sign of a cynical nature) that I should have come to view an event such as the FIFA World Cup as the proverbial Trojan horse: the relevant sports governing body, commercial actors and (sometimes) corrupt officials in the host nation wheel and deal to turn a quick and very lucrative buck, while the populace is seduced by the promise of an exciting sporting spectacle - "while the sinners sin, the children play ... how they play and play for that happy day". ${ }^{188}$ Greed and opportunism are natural and sadly unsurprising human instincts, but what really worries me is when custommade law is used to protect and promote such conduct and to legitimize these practices that probably hold little benefit for the common good. Having said that the 2010 FIFA event has generally been hailed as a huge success, it must also be said that South Africans will probably for years to come have to count the true costs of hosting this spectacle. In the months following the event it has become clear that (as so many expected) the expensive and state-of-the-art new World Cup stadia will for the most part be costly white elephants in years to come (the Cape Town stadium being a prime example). During the finalization of this article for publication (in October 2010) it has also been reported that the host cities are reportedly still awaiting payment of an amount in the region of ZAR 500 million from FIFA (representing the host cities' share of ticket sales). The World Cup legislation has clearly served to protect narrow commercial interests for FIFA and its partners (for whom the event was undoubtedly a commercial success), but the benefits for the South African public, whose rights and freedoms were so significantly curtailed, remain elusive. It is sincerely hoped that the legal fraternity and others will consider the potential dangers critically, with a view to evaluating suggestions for the future in respect of the hosting of major international sporting events.

I will stop short of proposing a practical way forward or magical panacea to address the problems referred to here, except to consider, for example, the (perhaps far-fetched?) possibility of a multi-lateral international convention regarding the organization of major sporting events and the regulation of commercial matters connected therewith. In the football context, would FIFA be discouraged or prohibited from exerting pressure on potential World Cup hosts to pass invasive anti-ambushing legislation if the majority of prominent football nations have all agreed to a ceiling of commercial-rights protection (or, for example, an anti-ambushing legislation template) and to mutual guarantees of certain rights and freedoms? Would such an instrument remove the temptation for FIFA to threaten to take their event elsewhere (a threat that it apparently loves to make ${ }^{189}$ ), if it knows that

${ }^{188}$ From "Tea for the Tillerman" (Cat Stevens Tea for the Tillerman (C) 1970, A\&M/Island Records).

189 The South African organizers of the 2010 FIFA World Cup apparently experienced difficulty earlier in negotiations with FIFA regarding ticket prices for the event. While the organizers (and other forums across Africa) insisted that tickets should be affordable to the masses, FIFA reportedly pegged the prices, insisting on the maximization of profits in order to finance their own activities for the four years until the next World Cup. Apparently, FIFA have 
no major football market will allow it to insist on the trampling of their citizens' rights in order to protect a few already wealthy corporations' financial interests?

In the meantime, in this humble observer's opinion, I truly hope that one of our beautiful cities will not bid for and be awarded the Olympic Games anytime soon. ${ }^{190}$ I might just have to pack my bags and move to Switzerland for the duration. It must be quite nice there when FIFA and the IOC are out of town ...*

emphasized the fact that the event is a FIFA event and that South Africa has little bargaining power in this respect - even to the point of stating that the organization could take away the World Cup if they chose (from a briefing to the parliamentary Portfolio Committee on Sport and Recreation, Cape Town, 14 June 2005).

190 The South African Sports Confederation and Olympic Committee (SASCOC) reportedly announced on 12 July 2010 that a proposed Olympic Games bid for either the 2020 or 2024 event was being investigated, following the success of the 2010 FIFA World Cup and a meeting between President Jacob Zuma and the President of the International Olympic Committee, Dr Jaques Rogge, immediately after the end of the FIFA event in July 2010. Durban has since emerged as the only South African city prepared to bid for the Games.

* The author has commenced writing a book for the international market (to be published as part of the international sports law series of the TMC Asser Press, The Hague), which will further examine the issues raised in this series of articles. This book, which it is hoped will be completed by end 2011, will broaden the focus beyond the 2010 FIFA Wold Cup South Africa (to include the other major international sporting mega-events, including the 2012 London Olympic Games, the IRB Rugby World Cup and ICC Cricket World Cup events, as well as the 2014 FIFA World Cup Brazil) and beyond South African law (to include other jurisdictions such as the UK, Europe, the USA, Brazil, China, India, Australia and New Zealand). The book's main focus will be a critical evaluation of what the author views as the potentially illegitimate ways in which domestic laws are used to protect and maintain commercial monopolies in sporting mega-events. 